Библиография произведений Н.В. Гоголя и литературы о нем на русском языке (2017)

V.A. Voropaev (Moscow, Russia)

\title{
The Bibliography of N.V. Gogol's Works and Literature about Him in Russian (2017)
}

\section{ПРОИЗВЕДЕНИЯ}

Афоризмы, изречения, сентенции / Сост. Т. Михед, П. Михед; вступ. статья П. Михеда. [Изд. 2-е.] СПб.: Изд-во «Пушкинский Дом», 2017. 256 с.: ил.

Загл. вступ. статьи: О «густом, могучем слове» Николая Гоголя: С. 5-16.

Вечера на хуторе близ Диканьки: [сб.] М.: Изд-во АСТ, 2017. 320 с. - (Эксклюзив: Русская классика).

Вечера на хуторе близ Диканьки: [сб.] М.: Изд-во Э, 2017. 317, [1] с. - (Серия Pocket book). Содерж.: Вечера на хуторе близ Диканьки; Вий.

Вечера на хуторе близ Диканьки; Миргород: повести. М.: Мартин, 2017. 445, [2] с. (Избранная культовая классика). - (Pocket book).

Вечера на хуторе близ Диканьки. М.: Изд-во Э, 2017. 317, [1] с. - (Серия 100 главных книг). Содерж.: Вечера на хуторе близ Диканьки; Вий.

Вий: повести / Худож. А. Лебедев. М.: Стрекоза, 2017. 157, [2] с.: ил. - (Школьная программа).

Содерж.: Вий; Вечер накануне Ивана Купала; Страшная месть.

Духовное завещание: иллюстрированное издание. М.: Изд-во «Э», 2017. 576 с.: ил. (Подарочное издание. (Российская императорская библиотека). - (Подарочные издания. Российская императорская библиотека).

[Примеч. в тексте.]

Содерж.:

Об этой книге. От Издательства. С. 5-10.

Предисловие к теме Гоголя. С. 11-13.

Статьи из сборника «Арабески»

О Средних веках. С. 14-27.

О преподавании всеобщей истории. С. 28-38.

Взгляд на составление Малороссии. С. 39-50.

Несколько слов о Пушкине. С. 51-55. 
Об архитектуре нынешнего времени. С. 56-70.

Ал-Мамун (Историческая характеристика). С. 71-75.

Жизнь. С. 76-78.

Шлёцер, Миллер и Гердер. С. 78-82.

О малороссийских песнях. С. 83-89.

Мысли о географии (Для детского возраста). С. 90-97.

Последний день Помпеи (Картина Брюллова). С. 98-103.

О движении народов в конце V века. С. 104-120.

Статьи и рецензии 1831-1846 гг.

Женщина. С. 122-128.

О движении журнальной литературы в 1834 и 1835 году. С. 129-143.

Петербургские записки 1836 года. С. 144-152.

«Исторические афоризмы» Михайла Погодина. С. 153-156.

О «Современнике» (Письмо к П.А. Плетневу). С. 157-164.

Выбранные места из переписки с друзьями

Главная книга. С. $165-166$.

Предисловие. С. 167-168.

І. Завещание. С. 169-173.

II. Женщина в свете (Письмо к ...ой). С. 174-176.

III. Значение болезней (Из письма к гр. А.П. Т...му). С. 177-178.

IV. О том, что такое слово. С. 179-180.

V. Чтения русских поэтов перед публикою (Письмо к Л.). С. 181-182.

VI. O помощи бедным (Из письма к А.О. С...ой). С. 182-183.

VII. Об «Одиссее», переводимой Жуковским (Письмо к Н.М. Я...ву). С. 184-189.

VIII. Несколько слов о нашей Церкви и духовенстве (Из письма к гр. А.П. Т...му). С. 190-191.

IX. О том же (Из письма к гр. А.П. Т...му). С. 191-192.

Х. О лиризме наших поэтов (Письмо к В.А. Ж...му). С. 193-200.

ХІ. Споры (Из письма к Л.). С. 201-202.

ХІІ. Христианин идет вперед (Письмо к Щ...ву). С. 202-203.

XIII. Карамзин (Из письма к Н.М. Я...ву). С. 204-205.

XIV. O театре, об одностороннем взгляде на театр и вообще об односторонности (Письмо к гр. А.П. Т...мy). С. 206-217.

XV. Предметы для лирического поэта в нынешнее время (Два письма к Н.М. Я....у). С. 218-220.

XVI. Советы (Письмо к Щ...ву). С. 221-222.

XVII. Просвещение (Письмо к В.А. Ж....му). С. 222-223.

XVIII. Четыре письма к разным лицам по поводу «Мертвых душ». С. 224-232.

ХIX. Нужно любить Россию (Из письма к гр. А.П. Т...му). С. 233-234.

ХХ. Нужно проездиться по России (Из письма к гр. А.П. Т...му). . С. 235-239.

XXI. Что такое губернаторша (Письмо к А.О. С...ой). С. 240-249.

XXII. Русский помещик (Письмо к Б.Н. Б...му). С. 250-254.

XXIII. Исторический живописец Иванов (Письмо к гр. Матв. Ю. В...му). С. 255-260.

XXIV. Чем может быть жена для мужа в простом домашнем быту, при нынешнем порядке вещей в России. С. 261-263.

XXV. Сельский суд и расправа (Из письма к М.). С. 264-265.

XXVI. Страхи и ужасы России (Письмо к графине ...oŭ). С. 265-267.

XXVII. Близорукому приятелю. С. 268-269.

XXVIII. Занимающему важное место. С. 269-281.

XXIX. Чей удел на земле выше (Из письма к У....мy). С. 282-283.

XXX. Напутствие. С. 283

XXXI. В чем же наконец существо русской поэзии и в чем ее особенность. С. 284-309.

XXXII. Светлое Воскресенье. С. 310-317.

Голоса и отголоски. О «Выбранных местах из переписки с друзьями»

Вяземский П.А. Языков и Гоголь. С. 318-327.

Приписка. С. 328-331. 
Белинский В.Г. «Выбранные места из переписки с друзьями» Николая Гоголя. С. 332-347.

Гоголь Н.В. Письмо В.Г. Белинскому. С. 348-350.

Белинский В.Г. Письмо Н.В. Гоголю. С. 351-360.

Гоголь Н.В. Ответ Белинскому. С. 361-368.

Аксаков С.Т. Из «Истории моего знакомства с Гоголем». С. 369-371.

Аксаков С.T. - Аксакову И.С. 11 января 1847 г. С. 372.

Аксаков С.Т. - Аксакову И.С. 14 января 1847 г. С. 373-374.

Аксаков С.Т. - Аксакову И.С. 16 января 1847 г. С. 375-382.

Григорьев А.А. Гоголь и его последняя книга. С. 383-397.

Писемский А.Ф. [Высказывания о Гоголе.] С. 398-401.

В орбите «Выбранных мест»

Гоголь Н.В. О тех душевных расположениях и недостатках наших, которые производят в нас смущение и мешают нам пребывать в спокойном состоянии.

О гневе. С. 402-403.

О боязни, мнительности и неуверенности в себе. С. 404-405.

Об унынии. С. 406-407.

Правило жития в мире. С. 408-410.

О сословиях в государстве. С. 411-414.

Авторская исповедь. С. 415-440.

Письмо Нащокину. С. 441-446.

Гоголь в воспоминаниях и оценках

Никитенко А.В. Дневниковые записи

26 февраля 1852 года. С. 447.

28 апреля 1852 года. С. 447.

4 октября 1860 года. С. 448.

5 ноября 1860 года. С. 448.

Герцен А.И. О развитии революционных идей в России

Гл. 5: Литература и общественное мнение после 14 декабря 1825 года. С. 449-451.

Григорьев А.А. Взгляд на русскую литературу со смерти Пушкина. Статья первая. Пушкин Грибоедов - Гоголь - Лермонтов. С. 452-461.

Розанов В.В.

Легенда о Великом Инквизиторе Ф.М. Достоевского. Опыт критического комментария. С. 462-468. Пушкин и Гоголь. С. 469-475.

Послесловие к комментарию «Легенды о Великом Инквизиторе Ф. М. Достоевского». С. 476-477.

Мережковский Д.С. Гоголь и черт. Часть ІІ. Жизнь и религия. С. 478-522.

Бельй Андрей. Гоголь. С. 523-533.

Брюсов В.Я. Испепеленный (К характеристике Гоголя). С. 534-548.

Овсянико-Куликовский Д.Н. История русской интеллигенции. Часть I

Гл. IX: «Люди 40-х годов» и Гоголь. С. 549-552.

Гл. Х: Тип Тентетникова и вторая часть «Мертвых душ». С. 553-568.

Заключение. С. 569.

Записки сумасшедшего: [сб.] М.: Изд-во АСТ, 2017. 256 с. - (Эксклюзив: Русская классика).

\section{Содерж.:}

Шинель. С. 3-46.

Невский проспект. С. 47-95.

Hoc. C. 96-130.

Портрет. С. 131-207.

Записки сумасшедшего. С. 208-237.

Коляска. С. 238-253.

Записки сумасшедшего: повести / Вступ. статья В.М. Марковича; коммент. Е.С. Чертковой. СПб.; Киев: Азбука Азбука-Аттикус Махаон-Украина, 2017. 284, [2] с. - (Азбука-классика).

Загл. вступ. статьи: Безумие и норма в петербургских повестях Гоголя. С. 5-30. 
Коммент. С. 257-285.

Содерж.: Повести: Невский проспект; Нос; Портрет; Записки сумасшедшего. Приложение: Портрет (редакция «Арабесок»).

Мертвые души: поэма М.: Изд-во АСТ, 2017. 317, [2] с. - (Классика для школьников). (Рекомендовано лучшими учителями).

Мертвые души: поэма. М.: Изд-во АСТ, 2017. 317, [2] с. - (Школьное чтение).

Мертвые души: [поэма. Т. 1.] М.: АСТ, 2017. 352 с. - (Эксклюзив: Русская классика).

Мертвые души: поэма. СПб. [и др.]: Азбука [и др.], 2017. 348, [2] с. - (Азбука-классика).

Миргород: повести / Худож. А. Симанчук. М.: Искателькнига Искатель, 2017. 93, [1] с. (Библиотечка школьника).

Содерж.: Повесть о том, как поссорились Иван Иванович с Иваном Никифоровичем; Старосветские помещики; Вий.

Ночь перед Рождеством. СПб.: Литера, 2017. 62, [1] с. - (Внеклассное чтение).

Нужно любить Россию / Сост., предисл. и коммент. В.А. Воропаева; отв. ред. О. Платонов. 2-е изд. М.: Институт русской цивилизации, Родная страна, 2017. 672 с.

Предисл. С. 5-15.

\section{Содерж.:}

Статьи из «Арабесок»:

Скульптура, живопись и музыка. С. 16-20.

О преподавании всеобщей истории. С. 20-34.

Взгляд на составлении Малороссии. С. 35-45.

Несколько слов о Пушкине. С. 45-51.

Ал-Мамун (Историческая характеристика). С. 51-57.

Жизнь. С. 57-60.

Шлецер, Миллер и Гердер. С. 60-65.

Мысли о географии (Для детского возраста). С. 65-74.

Последний день Помпеи (Картина Брюллова). С. 74-81.

Тарас Бульба. С. 82-203.

Выбранные места из переписки с друзьями. С. 204-424.

Духовная проза:

$<$ Авторская исповедь.> С. 425-463.

Искусство есть примирение с жизнью (Письмо к В.А. Жуковскому). С. 463-468.

Правило жития в мире. С. 468-473.

O тех душевных расположениях и недостатках наших, которые производят в нас смущение и мешают нам пребывать в спокойном состоянии. С. 473-482.

$<$ О благодарности. $>$ С. 483-484.

О сословиях в государстве. С. 484-489.

Размышления о Божественной Литургии. С. 489-541.

Молитвы, духовное завещание, предсмертные записи. С. 541-546.

Коммент. С. 547-667.

Петербургские повести / Вступ. статья и коммент. В.А. Воропаева; худож. Ф. Москвитин М.: Детская литература, 2017. 232 с.: ил. - (Школьная библиотека).

Загл. вступ. статьи: Гоголевский Петербург. С. 5-14.

Коммент. С. 211-233.

Петербургские повести / Худож. Ника Гольц. СПб.; М.: Речь, 2017. 252, [2] с.: ил. - (Серия Образ Речи).

Содерж.: Невский проспект; Нос; Портрет; Шинель; Записки сумасшедшего. 
Петербургские повести / Ил. Л.П. Подлясской. М.: Издательский дом Мещерякова, 2017. 173, [1] с.: ил - (Переживая заново).

Содерж.: Невский проспект; Нос; Портрет; Шинель.

Петербургские повести: [сб.] М.: АСТ, 2017. 380, [1] с. - (Серия Русская классика).

Содерж.: Повести: Невский проспект; Нос; Портрет; Шинель; Записки сумасшедшего; Коляска; Пьесы: Ревизор; Женитьба.

Петербургские повести; Ревизор: комедия. М.: Мартин, 2017. 286, [2] с. - (Избранная культовая классика). - (Pocket book).

Повести: (из цикла «Петербургские повести») / Худож. Ирина Минкина. Ростов-на-Дону: Проф-Пресс, 2017. 110, [1] с. - (Школьная библиотека).

Содерж.: Шинель; Нос; Записки сумасшедшего.

Ревизор: комедия в пяти действиях / Вступ. статья В.А. Воропаева; коммент. И.А. Виноградова, В.А. Воропаева; худож. В. Бритвин. М.: Детская литература, 2017. 128 с.: ил. - (Школьная библиотека). 3000 экз.

Загл. вступ. статьи: Над чем смеялся Гоголь. О духовном смысле комедии «Ревизор». С. 5-20. Коммент. С. 120-126.

Ревизор: комедия в пяти действиях. М.: АСТ, 2017. 188, [2] с. - (Школьное чтение). (Одобрено лучшими учителями).

Ревизор: комедия в пяти действиях. М.: АСТ, 2017. 188, [2] с. - (Классика для школьников). - (Рекомендовано лучшими учителями).

Ревизор: [комедия в пяти действиях] / Худож. А. Арестов]. Реутов: Омега, 2017. 170, [2] с.: ил. - (Школьная библиотека).

Ревизор: комедия в пяти действиях / Ил. А.И. Константиновского и др. Тверь: Мартин, 2017. 157, [3] с.: [4] л. цв. ил.: ил. - (Малая избранная классика). - (Малая избранная иллюстрированная классика. Драматургия).

Ревизор: комедии / Коммент. А. Степанова. СПб.: Азбука; Азбука-Аттикус, 2017. 317, [2] с. - (Азбука-классика).

Содерж.: Ревизор; Женитьба; Игроки; Утро делового человека; Тяжба; Лакейская; Отрывок; Театральный разъезд после представления новой комедии.

Ревизор: сб. М.: Изд-во АСТ, 2017. 224 с. - (Эксклюзив: Русская классика).

Содерж:

Ревизор. С. 5-138.

Женитьба. С. 139-221.

Ревизор: [сб.] М.: АСТ, 2017. 220, [2] с. - (Серия Эксклюзив: Русская классика). - (Книги, изменившие мир. Писатели, объединившие поколения).

Содерж.: Ревизор; Женитьба.

Ревизор; Женитьба: [комедии.] [2-е изд.]. М.: De Agostini, 2017. 313 с. - (Шедевры мировой литературы в миниатюре; вып. 40).

Ревизор: [комедия]; Шинель: [повесть.] М.: Изд-во Э, 2017. 156, [2] с. - (Классика в школе).

Россия. Путь истины. М.: РИПОЛ классик, 2017. 672 с. - (Русские мыслители).

Содерж.:

Статьи из «Арабесок»:

Предисловие к «Арабескам». С. 5.

Скульптура, живопись и музыка. С. 6-11.

О Средних веках. С. 11-24. 
Глава из исторического романа. С. 24-36.

Взгляд на составлении Малороссии. С. 36-47.

Несколько слов о Пушкине. С. 47-53.

Ал-Мамун (Историческая характеристика). С. 53-60.

Жизнь. С. 60-63.

Шлецер, Миллер и Гердер. С. 63-69.

Невский проспект. С. 69-110.

О малороссийских песнях. . 110-117.

Мысли о географии (Для детского возраста). С. 117-126.

Записки сумасшедшего. С. 126-151.

Критика и публицистика:

Выбранные места из переписки с друзьями. С. 152-391.

Размышления о Божественной Литургии. С. 391-449.

Переписка:

Переписка с Н.Я. Прокоповичем. С. 450-497.

Белинский В.Г. Письмо к Н.В. Гоголю. С. 497-504.

Григорьев А.А. Гоголь и его последняя книга. С. 505-528.

Жуковский В.А. Письма к Н.В. Гоголю. С. 529-538.

Приложение:

Мережковский Д.С. Гоголь. Творчество, жизнь и религия. С. 539-671.

[В сокращении.]

Сорочинская ярмарка: повести / Худож. С. Бабюк, А. Лебедев. М.: Стрекоза, 2017. 189, [2] с.: ил.: цв. ил. - (Внеклассное чтение).

Содерж.: Сорочинская ярмарка; Вий; Страшная месть.

Тарас Бульба: повесть / Вступ. статья В. Воропаева; коммент. И. Виноградова; худож. Е.А. Кибрик. М.: Детская литература, 2017. 190 с.: ил. - (Школьная библиотека). 3000 экз. Загл. вступ. статьи: Гражданин земли Русской. С. 5-12.

Коммент. С. $167-188$.

Тарас Бульба / Худож. А. Симанчук. М.: Искателькнига, 2017. 94, [1] с. - (Библиотечка школьника).

Тарас Бульба: редакция 1842 г. / Ил. Ю. Кравца. М.: Алтей и К Альтей-Бук, 2017. 144 с.: ил. - (Читаем в школе). - (Мировая классика).

Тарас Бульба: [повести.] М.: Изд-во «Э», 2017. 192 с. - (Классика в школе).

Содерж.:

Заколдованное место. С. 5-16.

Тарас Бульба. С. 17-189.

Тарас Бульба. Миргород: повести. М.: Вече, 2017. 320 с. - (100 великих романов).

Тарас Бульба: [сб.] М.: Изд-во АСТ, 2017. 320 с. - (Эксклюзив: Русская классика).

Содерж.:

Старосветские помещики. С. 5-36.

Тарас Бульба. С. 37-198.

Вий. С. 199-252.

Повесть о том, как поссорился Иван Иванович с Иваном Никифоровичем. С. 253-318.

Тарас Бульба: повести. СПб. [и др.]: Азбука [и др.], 2017. 316, [2] с. - (Азбука-классика).

Содерж.: Старосветские помещики; Тарас Бульба; Вий; Повесть о том, как поссорились Иван Иванович с Иваном Никифоровичем.

Шинель. М.: Изд-во Э, 2017. 64 с. - (Minibook). 
Шинель: петербургские повести / Художник Л. Сальникова. М.: Омега-пресс, 2017. $285,[1]$ с.: ил. - (Школьная библиотека).

Содерж.: Нос; Невский проспект; Портрет; Записки сумасшедшего; Шинель.

Шинель: [сб.] М., 2017. 96 с. - (Школьная классика).

Содерж.: Шинель, Нос, Старосветские помещики.

Шинель: повести / Рис: Е. Трофимовой. М.: Стрекоза, 2017. 285, [2] с.: ил. - (Школьная программа).

Содерж.: Невский проспект; Нос; Портрет; Шинель; Коляска; Записки сумасшедшего.

Шинель: [повести.] СПб.: Литера, 2017. 62, [2] с. - (Внеклассное чтение).

Содерж.: Невский проспект; Шинель.

\section{Л И Т Е РАТ У РА}

Абдуллаев А.А., Рамазанова Д.А. Актуальность поэмы Н.В. Гоголя «Мертвые души» // Известия Дагестанского гос. педагогического университета. Общественные и гуманитарные науки. Махачкала, 2017. Т. 11. № 2. С. 18-22.

Агафонова О.В. Конструктивный характер творчества Н.В. Гоголя в контексте неклассической теории познания // Международный научно-исследовательский журнал. Екатеринбург, 2017. № 12-2(66). С. 37-41.

$<$ Агапит (Беловидов), схиархимандрит>. Житие Оптинского старца Макария. Козельск: Введенский ставропигиальный мужской монастырь Оптина Пустынь, 2017. 512 с.: ил. - (Духовное наследие Оптиной Пустыни).

[О Гоголе: С. 311-313.]

Агеева 3. Душевная болезнь Гоголя: патография. Изд. 2-е, доп. и испр. М.: Алгоритм, 2017. 112 с.: ил.

Адамчук М. Реки крови близ Диканьки // Теленеделя. М., 2017. № 34. С. 16-17, 58.

[31 августа в прокат выходит фильм «Гоголь. Начало» (режиссер Егор Баранов, автор идеи Александр Цекало). Ожидаются оторванные головы, хоровод девушек-утопленниц и масса других страшилок.]

Акимова М.С. «Гоголь, или провинциал в столице»: от Малороссии к Петербургу // Научный диалог. Екатеринбург, 2017. № 6. С. 113-124.

Акимова Н.Н. Чью шинель украл Булгарин? Об одном из источников пушкинского текста // Вопросы литературы. М., 2017. № 3. С. 159-172.

Акопова Ю.А. Андрей Белый о значении Гоголя в самосознании русской культуры // Филология и культурология: современные проблемы и перспективы развития: сб. материалов XXVI международной научно-практической конференции (Махачкала, 22 мая 2017 г.). Махачкала, 2017. С. 15-18.

Акопова Ю.А. Андрей Белый о роли Гоголя в самосознании русской культуры // Современные тенденции развития науки и технологий. Белгород, 2017. № 2-5. С. 6-9.

[Материалы XXIII международной научно-практической конференции (Белгород, 28 февраля 2017 г.).]

Актуальные вопросы светской и духовной словесности. Вып. 1 / Российская академия наук. Институт мировой литературы им. А.М. Горького; редкол.: М.И. Щербакова (отв. ред.), О.А. Крашенинникова, Е.А. Осипова, Е.А. Самофалова. М.: ИПО «У Никитских ворот», 2017. $416 \mathrm{c}$.

Из содерж.:

Виноградов И.А. Самая патриотическая книга нашей словесности («Выбранные места из переписки с друзьями Николая Гоголя»). С. 77-94. 
Монахова И.Р. Духовный путь и проповедь Гоголя. С. 95-116.

Виноградов И.А. Сборник Н.В. Гоголя «Каноны и песни церковные» (обстоятельства и время составления). С. 117-130.

Актуальные вопросы филологической науки XXI века: сб. статей VI международной научной конференции молодых ученых (Екатеринбург, 10 февраля 2017 г.). Ч. 2: Современные проблемы изучения истории и теории литературы / Министерство образования и науки Российской Федерации, Уральский федеральный ун-т им. первого Президента России Б.Н. Ельцина, Институт социальных и политических наук; под общ. ред. Ж.А. Храмушиной [и др.] Екатеринбург, 2017. 252 с.

Из содерж.:

Меладшина Ю.В. Мотив странничества в романе В. Шарова «Возвращение в Египет». С. 28-34.

[На примере интертекстуального взаимодействия с произведениями Гоголя, в частности, поэмой «Мертвые души».]

Хавралева О.В. Дописывание классики» как вид литературной рецепции: о романе В.В. Шарова «Возвращение в Египет». С. 110-115.

[Гоголь как новый вид литературной рецепции.]

Алавердян Е.А. Личность и творчество Н.В. Гоголя в интерпретации В.В. Набокова // Традиционные национально-культурные и духовные ценности как фундамент инновационного развития России / Магнитогорский гос. технический ун-т им. Г.И. Носова. Магнитогорск, 2017. № 2(12). С. 80-83.

Александров С.Г. Отражение самобытных элементов физического воспитания запорожских казаков в творчестве Н.В. Гоголя // Голос минувшего: Кубанский исторический журнал / Кубанский гос. ун-т. Краснодар, 2017. № 1-2. С. 163-175.

Александров С.Г. Отражение самобытных элементов физического воспитания запорожских казаков в творчестве Н.В. Гоголя // Культурное наследие Северного Кавказа как ресурс межнационального согласия: сб. научных статей по итогам международного научного форума (с. Кабардинка, г. Геленджик, 30 сентября - 3 октября 2016 г.) / Российский научно-исследовательский институт культурного и природного наследия имени Д.С. Лихачева, Южный филиал; отв. ред. И.И. Горлова. Геленджик, 2017. С. 170-183.

Александрова Н.Ф. «...Такая долгая, такая жаркая печаль!» Занятие в рамках работы клуба любителей русской словесности «Живая классика» (обсуждение повести Н.В. Гоголя «Старосветские помещики») // Реализация ФГОС: опыт, проблемы, перспективы. Форум гуманитарных дисциплин: Материалы межрегиональной научно-практической конференции (Липецк, 22 ноября 2017 г.) / Институт развития образования Липецкой области. Липецк, 2017. С. 258-264.

Алексеев A.A. Воздействие Свято-Введенской Оптиной Пустыни на русскую литературу XIX века // Вестник Шадринского гос. педагогического ун-та. Шадринск, 2017. № 4(36). C. 107-114.

[В частности, Гоголь и Оптина Пустынь.]

Аль-Масуд Мохаммед Кадим Хассун. Автор и отражение его авторской позиции в произведениях Н. Гоголя и Султана бин Мухаммад Аль-Касими: компаративный аспект // Альманах современной науки и образования. Тамбов, 2017. № 4-5(118). С. 10-14.

Алексеев П.В. «Китайское» вступление к «Дневнику писателя» Ф.М. Достоевского // Вестник Томского гос. ун-та. Филология. Томск, 2017. № 49. С. 98-112.

[Китайские мотивы во «Вступлении» к «Дневнику писателя» Ф.М. Достоевского (1873); интертекстуальные и типологические взаимосвязи с повестью Гоголя «Записки сумасшедшего»].

Арпентьева M.Р. «Маленький человек»: Н. Гоголь, А. Чехов, М. Зощенко // Культурные коды русской литературы: Материалы всероссийской (с международным участием) очно-заочной научно-практической конференции, посвященной 60-летию филологиче- 
ского факультета Башкирского гос. ун-та (Уфа, 15 декабря 2017 г.) / Башкирский гос. ун-т; отв. ред. А.В. Курочкина. Уфа. 2017. С. 209-221.

Архангельский А. Хоррор имени Пятницкого // Огонек. М., 2017. № 34. С. 37.

[В прокат выходит «Гоголь. Начало» (режиссер Егор Баранов, автор идеи - Александр Цекало) - первый из четырех фильмов нового проекта по мотивам произведений классика. Обозреватель «Огонька» честно попытался понять логику нечисти - но зло оказалось совершенно иррациональным.]

Ахмадова T.X. Пословицы и поговорки в поэме Н.В. Гоголя «Мертвые души» // 6 ежегодная итоговая конференция профессорско-преподавательского состава Чеченского гос. ун-та (Грозный, 2 марта 2017 г.). Гуманитарные науки / Отв. ред. Р.А. Кутуев. Грозный, 2017. С. 63-68.

Ахмадова T.X. Традиции Н.В. Гоголя в творчестве М.Е. Салтыкова-Щедрина // World science: problems and innovations: сб. статей XVI международной научно-практической конференции (Пенза, 25 декабря 2017 г.): В 3 ч. Ч. 3 / Отв. ред. Г.Ю. Гуляев. Пенза, 2017. C. $55-61$.

Баль В.Ю. Образ Чичикова в современной русской прозе // Вестник Томского гос. унта. Филология. Томск, 2017. № 49. С. 147-168.

[Рецепция образа Чичикова (поэма Гоголя «Мертвые души») в современной русской прозе конца XX - начала XXI в.]

Басинский П. Новый «Гоголь» явился // Российская газета. М., 2017. 2 октября. С. 9.

[Фильм «Гоголь. Начало» режиссера Егора Баранова не обманул мои ожидания, потому что, по правде говоря, никаких особых ожиданий у меня перед просмотром и не было.]

Бачалова И.Б., Хунарикова П.Х. Гоголь и Гофман (к проблеме гротеска) // Казанская наука. Казань, 2017. № 1. С. 26-30.

Безвременье как сюжет: статьи и материалы. Вып. 6 / Тверской гос. ун-т; ред. С.А. Васильева, А.Ю. Сорочан. Тверь, 2017. 340 с.

Из содерж.:

Никииов Ю.М. О попытках пресечь безвременье «вечевым» временем. С. 130-141.

[Попытки Гоголя и А.С. Грибоедова повлиять на общественную жизнь.]

Карандашова О.С. К вопросу о временной организации гоголевского «Миргорода». С. 205-210. [Вечность и безвременье в «Миргороде» Гоголя.]

Белов А.В. Итоги реформы города Екатерины II в контексте критической оценки современников. Комедия «Ревизор» и поэма «Мертвые души» Н.В. Гоголя // Вестник славянских культур. М., 2017. Т. 44. С. 43-49.

Белюченко О.П., Нагорный И.А. Языковые средства и способы выражения эмоциональности в произведениях Н.В. Гоголя // Научные исследования. Иваново, 2017. № 1(12). С. 46-47.

Беляков С. «Тарас Бульба» между Украиной и Россией. О национальной идентичности героя Гоголя // Вопросы литературы. М., 2017. № 6. С. 191-220.

Берестовская Д. Идеи духовной целостности культуры в концепции В.В. Зеньковского («Русские мыслители и Европа») // Культура в фокусе научных парадигм / Донецкий национальный ун-т. Донецк, 2017. № 5. С. 24-28.

[В частности, Гоголь в концепции протопресвитера В.В. Зеньковского.]

Берестовская Д.С. Писатель С.Н. Сергеев-Ценский как «художник слова» // Ученые записки Крымского федерального ун-та им. В.И. Вернадского. Философия. Политология. Культурология. Симферополь, 2017. Т. 3(69). № 3. С. 106-113.

[В частности, С.Н. Сергеев-Ценский о Гоголе.] 
Бобылев Б.Г. Филологический анализ и эстетическая коммуникация: имманентный подход // Научные исследования и разработки. Современная коммуникативистика. М., 2017. Т. 6. № 6. С. 56-62.

[На примере повести Гоголя «Шинель».]

Бобылев Б.Г. «Филологический круг» как основа технологии анализа художественного текста в школе // Гуманитарные технологии в современном мире: Материалы V всероссийской научно-практической конференции с международным участием (Калининград, 25-27 мая 2017 г.) / Российская академия народного хозяйства и государственной службы при Президенте Российской Федерации. Западный филиал. Калининград, 2017. C. 27-30.

[На примере повести Гоголя «Шинель».]

Богданова О.В. Д.Д. Шостакович в контексте «носологии» Н.В. Гоголя // Вестник Русской христианской гуманитарной академии. СПб., 2017. Т. 18. № 4. С. 267-281.

[Музыкальная интерпретация Д.Д. Шостаковичем повести Гоголя «Нос».]

Богданова О.В. Повесть Н.В. Гоголя «Нос»: олицетворенная синекдоха / Санкт-Петербургский гос. ун-т; Филологический факультет. СПб., 2017. 37 с.: ил. - (Серия Литературные направления и течения; вып. 90; Анализ литературного произведения; Петербургская филологическая школа).

Большакова Н.В. Комментарии к 1-му тому поэмы Н.В. Гоголя «Мертвые души». 2-е изд. М.: Издательский дом «Сказочная дорога», 2017. 520 с.

Приложение 1

Несуразицы в тексте поэмы. С. 498-514.

Приложение 2

Хронологическая справка «Отечественная война 1812 года и заграничный поход русской армии 1813-1814 годов». С. 514-517.

Бондарев А.Г. Границы текста и реальности в творчестве Н. Гоголя и Д. Хармса // Успехи современной науки и образования. Белгород, 2017. Т. 5. № 3. С. 7-10.

Боровская E.P. К истории одной фамилии в повести Н.В. Гоголя «Портрет» // Вестник Московского гос. лингвистического ун-та. Гуманитарные науки. М., 2017. № 772. С. 142-150. [Сравнительный анализ вариантов фамилии главного героя повести «Портрет» - художника Чарткова.]

Брянщева О.А. Гоголевский саспенс «Заколдованного места» // Вестник Луганского национального ун-та им. Владимира Даля. Луганск, 2017. Т. 1. № 4(6). С. 66-69.

Бударагин М. Николай Васильевич меняет профессию // Культура. М., 2017. № 30. С. 10. [В прокате стартовал мистический триллер «Гоголь. Начало» (режиссер Егор Баранов, автор идеи - Александр Цекало), удивительно простая лента, которая не понравится зрителю, но будет тепло принята профессиональным сообществом.]

Булатая E.B. Ирония в художественном тексте и специфика ее перевода на немецкий язык (на материале повестей Н.В. Гоголя) // Известия Юго-Западного гос. ун-та. Серия Лингвистика и педагогика. Курск, 2017. Т. 7. № 1(22). С. 15-22.

Булатая E.B. Повтор как средство актуализации иронического смысла в художественном тексте (на материале произведений Н.В. Гоголя и их перевода на немецкий язык) // Вестник Балтийского федерального ун-та им. И. Канта. Сер. Филология, педагогика, психология. № 1. Калининград, 2017. С. 13-18.

Булатая E.B. Синтаксические средства экспликации иронии в художественном тексте (на материале произведений Н.В. Гоголя) // Язык и культура: сб. материалов XXVII международной научно-практической конференции (Новосибирск, 20 января - 22 февраля 
2017 г.) / Центр развития научного сотрудничества; под общ. ред. С.С. Чернова. Новосибирск, 2017. С. 83-88.

Булатая E.B. Стилистические средства выражения иронии в поэме Н.В. Гоголя «Мертвые души»: прагматический и переводческий аспекты // Национально-культурный компонент в тексте и языке: Материалы VI международной научной конференции, посвященной памяти проф. С.М. Прохоровой (Минск, 3-5 декабря 2015 г.) / Минский гос. лингвистический ун-т; отв. ред. О.А. Полетаева. Минск, 2017. С. 121-124.

Буркова B.A. Изображение ведьм у Гоголя и Булгакова: смех как отражение сознания русской ведьмы // Литература и язык в современном поликультурном пространстве: сб. статей по материалам всероссийской научно-практической конференции молодых ученых (Стерлитамак, 15 мая 2017 г.) / Стерлитамакский филиал Башкирского гос. унта; отв. ред. Г.М. Ибатуллина. Стерлитамак, 2017. С. 32-42.

Бутенина E.M. Рецепция прозы Гоголя в США // Американистика на Дальнем Востоке: Ежегодный бюллетень. Вып. 3 / Благовещенский гос. педагогический ун-т; отв. ред. Д.В. Кузнецов. Благовещенск, 2017. С. 10-13.

[Краткий обзор англоязычных исследований творчества Гоголя и переводов его произведений на английский язык; примеры включения гоголевского интертекста в современной прозе США.]

В преддверии Русской Палестины: Летопись Русской Духовной Миссии в Иерусалиме. 1847-1854 / Русская Духовная Миссия в Иерусалиме, Институт мировой литературы им. А.М. Горького РАН; сост., подгот. текста, вступ. статья и коммент. М.И. Щербаковой. Иерусалим, 2017. 352 с.: ил.

Загл. вступ. статьи: Введение. С. 14-28.

[Указ. имен.]

Варламова Н. Горький смех не понять фарцовщикам. Рецензия на фильм «Гоголь. Начало» // Русская народная линия. 22.09.2017.

[О первой части трилогии фильма «Гоголь» (режиссер Е. Баранов, автор идеи А. Цекало).

Варламова Н. Фарца в кривом зерцале. Вторая часть рецензии на к/ф-трилогию «Гоголь» // Русская народная линия. 10.11.2018.]

Василевская Н.А. Способы создания образов персонажей в поэме Н.В. Гоголя «Мертвые души» и героической повести «Тарас Бульба» // Молодой ученый. Казань, 2017. № 31(165). С. 77-83.

Васильева A. По следам гоголевских персонажей, или новые истории обитателей Диканьки // Библиотека. М., 2017. № 1. С. 17.

Васильева Ж. Гоголь. Начало // Российская газета. М., 2017. 27 сентября. С. 13

[В Третьяковской галерее открылась выставка «Скульптор Николай Андреев. Кем вы были до 1917 года». Споры о памятнике Гоголю на Никитском бульваре в Москве.]

Васиярова О.А. Как сделана «Шинель» Тынянова // Поволжский педагогический вестник / Самарский гос. социально-педагогический ун-т. Самара. 2017, Т. 5. № 4(17). С. 43-47.

[Киносценарий Ю.Н. Тынянова по повести Гоголя «Шинель».]

Ваулина С.С., Булатая E.B. Текстовые средства экспликации иронии как компонента авторской модальности в произведениях Н.В. Гоголя // Международный научно-исследовательский журнал. Екатеринбург, 2017. № 4-2(58). С. 20-23.

Вересаев В.В. Гоголь в жизни. М.: Изд-во АСТ, 2017. 768 с. - (Русская классика).

Виноградов И.А. Блаженны миротворцы. От повести о двух Иванах к замыслу «Мертвых душ» // Вестник Московского ун-та. Сер. 9. Филология. М., 2017. № 3. С. 7-18. 
Виноградов И.А. Блаженны миротворцы. От повести о двух Иванах к замыслу «Мертвых душ» (продолжение) // Вестник Московского ун-та. Сер. 9. Филология. М., 2017. № 4. C. 51-67.

Виноградов И.А. Гоголь и западное славянофильство: К постановке проблемы // Studia Litterarum. M., 2017. № 4. C. 182-207 (studlit.ru/images/2017-2-4/SL-2017-Vol2-4.pdf).

Виноградов И.А. Летопись жизни и творчества Н.В. Гоголя (1809-1852). С родословной летописью (1405-1808). Научное издание: В 7 т. Т. 1: 1405-1808; 1809-1828 / Российская академия наук. Институт мировой литературы им. А.М. Горького. М.: ИМЛИ PAH, 2017. $736 \mathrm{c}$.

Предисловие. С. 5-6.

Летопись рода Гоголя. С. 7-212.

Летопись жизни и творчества Н.В. Гоголя (1809-1852). 1809-1828. С. 213-694.

Список сокращений.

Указ. имен.

Географическая канва жизни и творчества Гоголя. 1809-1828. С. 727-730.

Виноградов И.А. Летопись жизни и творчества Н.В. Гоголя (1809-1852). Научное издание: В 7 т. Т. 2: 1829-1836 / Российская академия наук. Институт мировой литературы им. А.М. Горького. М.: ИМЛИ РАН, 2017. 672 с.

Указ. имен.

Географическая канва жизни и творчества Гоголя. 1829-1836. С. 659-670.

Виноградов И.А. Летопись жизни и творчества Н.В. Гоголя (1809-1852). Научное издание: В 7 т. Т. 3: 1837-1841 / Российская академия наук. Институт мировой литературы им. А.М. Горького. М.: ИМЛИ РАН, 2017. 672 с.

Указ. имен.

Географическая канва жизни и творчества Гоголя. 1829-1836. С. 650-670.

Виноградов И.А. Провокация вымысла: Мистифицированная цитата Д.С. Мережковского как литературная реалия в изучении Н.В. Гоголя // Проблемы исторической поэтики / Петрозаводский гос. ун-т; гл. ред. В.Н. Захаров. Петрозаводск, 2017. Т. 15. № 4 C. 7-21 (poetica.pro/files/redaktor_pdf/1512469843.pdf).

Виноградов И.А. Самая патриотическая книга нашей словесности («Выбранные места из переписки с друзьями Николая Гоголя») // Литературный факт: научный журнал. М.: ИМЛИ РАН, 2017. № 5. С. 416-426.

Водолагин А. Сильные мысли о России: Н.В. Гоголь и славянофилы // Наш современник. М., 2017. № 11. С. 240-253.

Волкова Е.В. Ключевые мифологические образы, мотивы и темы в повести Н.В. Гоголя «Вечер накануне Ивана Купалы» // Материалы Научной сессии 2017 (Борисоглебск, 1-30 апреля 2017 г.) / Борисоглебский филиал Воронежского гос. ун-та. Борисоглебск, 2017. C. 58-62.

Bоропаев B.A. Библиография произведений Н.В. Гоголя и литературы о нем на русском языке. 2015 // Stephanos. M., 2017. № 1(21). Январь. С. 249-279 (www.stephanos.ru).

Bоропаев B.A. Библиография произведений Н.В. Гоголя и литературы о нем на русском языке. 2016 // Stephanos. M., 2017. № 3(23). Май. С. 190-213 (www.stephanos.ru).

Boponaев B.A. Библиография произведений Н.В. Гоголя и литературы о нем на русском языке. 1986-1989 // Stephanos. M., 2017. № 5(25). C. 198-239 (www.stephanos.ru).

Воропаев В.A. Библиография произведений Н.В. Гоголя и литературы о нем на русском языке. 1981-1985 // Stephanos. 2017. № 6(26). C. 261-310(www.stephanos.ru). 
Boponaев B. Благословение Святой Горы: Русский Афон в судьбе Гоголя // Православная беседа. М., 2017. № 5. С. 82-89.

Boponaев B.A. Благословение Святой Горы: Русский Афон в судьбе Гоголя // Язык, литература, культура: Актуальные проблемы изучения и преподавания: сб. научных и научно-методических статей / Московский гос. ун-т имени М.В. Ломоносова. Филологический факультет, кафедра русского языка для иностранных учащихся гуманитарных факультетов; редкол.: Л.П. Клобукова и др. Вып. 13. М.: МАКС Пресс, 2017. С. 127-134.

Boponaев B.A. Был ли Гоголь в Испании: современный взгляд // История русской литературы: современность классики: сб. к юбилею проф. С.А. Джанумова / Московский городской педагогический ун-т; отв. ред. Н.И. Райкова. М.: Книгодел; МГПУ, 2017. С. 123-134.

Boponaев B.A. Всероссийская научная конференция «Поэма Н.В. Гоголя «Мертвые души»: история и современность» на филологическом факультете МГУ // Вестник Московского ун-та. Сер. 9. Филология. М., 2017. № 4. С. 261-265.

Boponaев B.A. Православный Гоголь в Сербии // Stephanos. M., 2018. № 2(28). С. 332333 (www.stephanos.ru).

[Рец. на кн.: Православни витез Николај Васиљевич Гогољ / Приредио и превео Ранко Гојковић. Стари Бановци; Београд: Бернар, 2017. 163 с. - (Библиотека Тихи глас).]

Boponaев B.A. Владимир Осипович Шервуд и Николай Васильевич Гоголь // Династия Шервудов в истории и культуре России / Министерство культуры Российской Федерации, Российская академия художеств, Государственный музей, Научно-исследовательский институт теории и истории изобразительных искусств при Российской академии художеств; авторы-сост. Е.А. Лукьянов, Ю.Р. Савельев; под науч. ред. Ю.Р. Савельева. М.: Фонд «Связь эпох»; «Кучково поле Музеон», 2017. С. 137-144.

Boponaев B.A. Гоголь и славянский мир. [Ч. 1] // Даниловский благовестник. М.: Изд-во Данилова ставропигиального мужского монастыря, 2017. № 33. С. 19-26.

Boponaев B.A. Да будет воля Твоя. К 165-летию со дня смерти Гоголя // Православное книжное обозрение. М., 2017. Декабрь. № 12(77). С. 25-33.

Boponaев B.A. «Да будет воля Твоя...» О причинах смерти Н.В. Гоголя // Кусковские чтения - 2017: Материалы международной научной конференции «Культурно-семиотическое пространство русской словесности: история развития и перспективы изучения» / Министерство образования и науки Российской Федерации, Московский гос. психолого-педагогический ун-т; сост. И.В. Дергачевой. М.: Кругъ, 2017. С. 9-20.

Bоропаев B.A. Духовник Гоголя. К 225-летию со дня рождения протоиерея Матфея Константиновского (1791-1857) // Даниловский благовестник. М.: Изд-во Данилова ставропигиального мужского монастыря, 2017. № 32. С. 27-38.

[Окончание. Начало см. «Даниловский благовестник». № 31.]

Bоропаев B.A. «Замечательный русский человек» // Православное книжное обозрение. М., 2017. Сентябрь. № 9(74). С. 66-68.

[Рец. на кн.: Расев А.И., <протоиерей>. Очерк жизни в Бозе почившего Ржевского протоиерея о. Матфея Александровича Константиновского: Сводная редакция (1860-1890-1915). Тверь, 2017. 496 c.]

Boponaев B.A. Из отроческих лет Гоголя // Странникъ: историко-литературный журнал. Смоленск, 2017. № 1(8). С. 28-34.

Boponaев B.A. «Ищите царствия Божия»: Святитель Филарет, митрополит Московский, и Гоголь. Из истории взаимоотношений. К 150-летию со дня кончины // Духовно-нравственное воспитание: научно-просветительский журнал. М., 2017. № 6. С. 20-23. 
Bоропаев В. «Меня очень занимал Гоголь». Из «Записок» В.О. Шервуда. К 185-летию со дня рождения // Православное книжное обозрение. М., 2017. № 10(75). Октябрь. С. 36-45.

Воропаев В.А. «Мертвые души» и цензура. К 175-летию выхода поэмы в свет (1842) // Московский журнал. М., 2017. № 11(323). Ноябрь. С. 2-6.

Bоропаев B. Молитва Гоголя // Православное книжное обозрение. М., 2017. № 3(69). Март. С. 24-32.

Boponaев B.A. Молитва Н.В. Гоголя ко Пресвятой Богородице в славянском фольклоре и литературном предании // Русистика без границ: международный научный журнал. София, 2017. № 3. С. 13-19.

Boponaев B.A. Н.В. Гоголь: Жизнь и творчество. В помощь преподавателям, старшеклассникам и абитуриентам. Изд. 6-е. М.: Изд-во Московского ун-та, 2017. 120 с. (Перечитывая классику).

Boponaев B.A. Н.В. Гоголь и святоотеческое наследие (к постановке проблемы) // Вестник Московского ун-та. Сер. 9. Филология. М., 2017. № 5. С. 9-20.

Boponaев B. Небесный Помещик и другие загадки «Мертвых душ» // Фома: православный журнал для сомневающихся. М., 2017. № 5(169). Май. С. 74-83.

[Беседовал Виталий Каплан; рис. Наталии Кондратовой.]

Boponaев B.A. Новое о Гоголе: источниковедческий обзор // Литературный факт: научный журнал. М.: ИМЛИ РАН, 2017. № 5. С. 427-438.

Boponaев B.A. Под защитой угодника Божия. Диканьский образ святителя Николая Чудотворца и его значение в жизни Н.В. Гоголя // Икона в русской словесности и культуре: Материалы XIII международной научной конференции «Икона в русской словесности и культуре» (Москва, 26-28 января 2017 г.) / Дом Русского Зарубежья, Музей Русской Иконы; ред.-сост. В.В. Лепахин. М., 2017. С. 268-276 (www.bfrz.ru/data/nayk_center/naychnuj_ sekretar/Sbornik_konferencia_2017_ikonichnost_slovesnost_zarubezhje_Lepahin_Prns.pdf).

Bоропаев B.A. Последнее свидание. К 160 -летию со дня кончины протоиерея Матфея Константиновского (1791-1857) и 165-летию со дня кончины Н.В. Гоголя (1809$1852) / /$ Православный собеседник: журнал Татарстанской митрополии. Казань, 2017. № 2(5). Май. С. 88-95.

Boponaев B.A. Протоиерей Матфей Ржевский как проповедник // Странникъ: историко-литературный журнал. Смоленск, 2017. № 1(8). С. 41-50.

[Публ. три проповеди отца Матфея.]

Boponaев B. Тайна великой поэмы. К 175-летию выхода в свет 1-го тома «Мертвых душ» // Православное книжное обозрение. М., 2017. № 5(71). Май. С. 58-63.

Boponaев B.A. Тайна великой поэмы. К 175-летию выхода в свет 1-го тома «Мертвых душ» // Литература в школе. М., 2017. № 12. С. 2-4.

Boponaев B.A. «Творение чисто русское, национальное». К 175-летию выхода в свет поэмы Н.В. Гоголя «Мертвые души»: история создания, жизнь и смерть автора. М., 2017. 32 с. - (Московский журнал. Приложение: «Мертвые души». 175 лет в поисках души живой).

Boponaев B.A. «Умереть с пеньем на устах...» Молитва Гоголя ко Пресвятой Богородице в славянском фольклоре и литературном предании // Русский вестник. М., 2017. 2 февраля. 
Bоропаев B.A. Филаретовская анкета [Отношение Гоголя к святителю Филарету, митрополиту Московскому] // Филаретовский альманах. Вып. 13 / Православный Свято-Тихоновский гуманитарный ун-т; редкол.: Г.В. Бежанидзе, протоиерей Павел Хондзинский, А.И. Яковлев (отв. ред.). М.: Изд-во ПСТГУ, 2017. С. 207-210.

Boponaев B.A. Чрезвычайное событие в литературоведении: издан трехтомный свод мемуаров и документальных свидетельств о Гоголе // Вестник Московского гос. областного ун-та. Сер. Русская филология. М., 2017. № 3. С. 149-151.

[Рец. на изд.: Гоголь в воспоминаниях, дневниках, переписке современников. Полный систематический свод документальных свидетельств. Научно-критическое издание: В 3 т. / Издание подготовил И.А. Виноградов. М.: ИМЛИ РАН, 2011-2013. Т. 1. М., 2011. 904 с. Т. 2. М., 2012. 1032 c. T. 3. M., 2013. 1168 c.] (vestnik-mgou.ru/Articles/View/10727).

Воскресенский Б.А. Духовный путь ученого: штрихи к портрету врача-психиатра Д.Е. Мелехова // Медицинская психология в России: электронный научный журнал 2017. Т. 9. № 1(42) (mprj.ru).

[«Душевная патология» Гоголя, описанная в работе Д.Е. Мелехова «Психиатрия и проблемы духовной жизни».]

Вострикова P.B. Морально-этические аспекты темы суда и правосудия в творчестве Н.В. Гоголя // Наука и инновации в современных условиях: сб. статей по материалам международной научно-практической конференции (Кемерово, 29 сентября 2017 г.) / Отв. ред. Е.Ю. Копылова. Шелехов, 2017. С. 34-40.

$<$ Выготский Л.С. $>$ Записные книжки Л.С. Выготского / Под общ. ред Екатерины Завершневой и Рене ван дер Веера. М.: Изд-во «Канон+», РООИ «Реабилитация», 2017. 608 с.

[Указ. имен.]

Вяземский Ю.П. Любовь в русской литературе. От Гоголя до Шолохова: [сб.] / Московский гос. институт международных отношений (университет) Министерства иностранных дел Российской Федерации. М.: АСТ, 2017. 320 с. - (Умники и умницы: олимпиада).

Галушко Т.Г. Н.В. Гоголь как пророк православной русской культуры // Шестые Пюхтицкие чтения: Материалы международной научно-практической конференции «Светское и духовное культурное наследие как ценностная основа формирования личности современника» (Куремяэ, Эстония, 11-12 декабря 2017 г.). / Пюхтицкий Успенский ставропигиальный женский монастырь. 2017. С. 170-176.

Галяткина Е.Н. Повесть Н. В. Гоголя «Портрет» в свете текстологии // Родное и вселенское: национальное своеобразие и мировое значение русской литературы. Эстетика, традиции, культурные приоритеты: сб. научных трудов. Вып. 5 / Отв. ред. А.А. Дырдин. Ульяновск, 2017. С. 18-54.

[Материалы международной научной конференции (Ульяновск, 29-30 сентября 2017 г.) / Ульяновский гос. технический ун-т; Открытое международное научное сообщество «Русская словесность: духовно-культурные контексты».]

Галяткина E.Н. Текстологический анализ двух редакций повести Н. В. Гоголя «Портрет» // Вестник Ульяновского гос. технического ун-та. Ульяновск, 2017. № 3(79). С. 10-22.

Гарифуллина Э.И. Н.В. Гоголь в эпистолярном наследии И.С. Тургенева 1852-1853 гг. // Филологические науки: состояние, перспективы, новые парадигмы исследований: Материалы международной заочной (электронной) научной конференции для молодых ученых, посвященной 60-летию филологического факультета / Башкирский гос. ун-т; отв. ред. А.Р. Мухтаруллина. Уфа, 2017. С. 78-85.

Гашева Н.Н. Литературная классика в рецепции кино: конфликт интерпретаций // Литература в системе культуры. К семидесятилетию проф. И.В. Кондакова: сб. статей по итогам международной научно-практической конференции (Москва, 15 апре- 
ля 2017 г.) / Министерство образования Московской области; Академия социального управления. М., 2017. С. 312-319.

[На примере экранизаций повести Гоголя «Вий» режиссерами Константином Ершовым и Георгием Кропачевым (1967 г.) и Олегом Степченко (2014 г.).]

Гоголезнавчі студії = Гоголеведческие студии / Редкол.: П.В. Михед (відп. ред.), С.Д. Абрамович, В.О. Воропаев, В.П. Казарин, О.С. Киченко [та ін.]; Ніжинський держ. ун-т ім. М. Гоголя; Гоголезнавчий центр; Інститут літератури ім. Т.Г. Шевченка НАН України. Вип. 6(23). Ніжин: ФОП Лук’яненко В.В. ТПК «Орхідея», 2017. 483 с. На рус. и укр. яз.

\section{Из содерж.:}

Абрамович С.Д. Чичиков как архетип тени. С. 6-23.

Виноградов И.А. Путешествие в творчестве Гоголя. С. 24-60.

Воропаев B.A. Молитва Гоголя «К Тебе, о Матерь Пресвятая...» в славянском фольклоре и литературном предании. С. 61-79.

Кривонос В.Ш. Отзвуки Гоголя в романе Д.С. Мережковского «Антихрист (Петр и Алексей)». C. 93-106.

Шульи С.А. Пушкин - Гоголь: к метафизике внутреннего диалога. С. 139-162.

Рецензії та відгуки

Boponaев B.A. Чрезвычайное событие в литературоведении: Издан трехтомный свод мемуаров и документальных свидетельств о Гоголе. С. 215-217.

[Рец. на кн.: Гоголь в воспоминаниях, дневниках, переписке современников. Полный систематический свод документальных свидетельств. Научно-критическое издание: В 3 т. / Издание подготовил И.А. Виноградов. М.: ИМЛИ РАН, 2011-2013.]

Якубина Ю.В. Над страницами новой книги о Гоголе. С. 218-230.

[Рец. на кн.: Виноградов И.А. Гоголь в Нежинской гимназии высших наук: Из истории образования в России. М.: ИМЛИ РАН, 2015. 352 с.]

Анкета Гоголезнавчих студій:

Абрамович С. С. 267-269.

Друбек Наташа. С. 270-271.

Бібліографія:

Bоропаев B.A. Библиография произведений Н.В. Гоголя и литературы о нем на русском языке (2009-2013): дополнения. С. 272-319.

Воропаев В.А. Библиография произведений Н.В. Гоголя и литературы о нем на русском языке (2014-2015). C. 320-440.

Воропаев В.A. Список авторефератов диссертаций, посвященных творчеству Н.В. Гоголя (2014-2016). C. 441-444.

Костенко О.О., Кузьменко Н.В., Михед П.В. Бібліографія України про життя і творчість Миколи Гоголя (2014-2015). С. 445-465. На рус. и укр. яз.

Зміст попередніх випусків «Гоголезнавчих студій». С. 466-475.

Гоголь и славянский мир. Шестнадцатые Гоголевские чтения: сб. научных статей по материалам международной научной конференции (Москва, 29 марта; Белград, 30 марта - 4 апреля 2016 г.) / Департамент культуры г. Москвы; «Дом Н.В. Гоголя - мемориальный музей и научная библиотека»; под общ. ред. В.П. Викуловой. М.; Новосибирск: Новосибирский издательский дом, 2017. 304 с.: ил.

\section{Содерж.:}

Summary. Аннотированное содержание на английском языке. - C. 7-13.

$<$ Приветственные слова участникам чтений.> С. 14-19.

Викулова В.П. Предисловие. С. 20-22.

Творчество Гоголя в славянском контексте:

Bоропаев В.А. Н.В. Гоголь и славянский фольклор. С. 24-34.

Гольденберг А.Х. Поэтика Гоголя в контексте славянской народной культуры. С. 35-42.

Анненкова Е.И. Гоголь и братья Аксаковы: славянский вопрос в историко-культурной перспективе. С. 43-53.

Манн Ю.В. Гоголь между западниками и славянофилами: опыт примирения. С. 54-59.

Гуминский В.М. Гоголь и славянофилы: к проблеме самобытного развития русской литературы. C. 60-68. 
Виноградов И.А. Славянофильство русское, польское и украинское: Н.В. Гоголь, А. Мицкевич и О.М. Бодянский. С. 69-77.

Есаулов И.А. Гоголь в русском и славянском контекстах понимания: парадоксы рецепции. C. $78-83$.

Барабаш Ю.Я. «Все эти славянисты и европисты...» (гоголевская тема: версия Юрия Шереха). C. 84-95.

Борисенкова А.В., Сугай Л.А. Европа и Россия в историко-культурных воззрениях Н.В. Гоголя. C. 96-103.

Балакшина Ю.В. Славянская и европейская «бестолковщина» (к проблеме художественного образа-итога в творчестве Н.В. Гоголя). С. 104-111.

Мильдон В.И. Сократ о Чичикове, или О степени античного влияния на славянскую культуру. C. $112-117$.

Дмитриева E.E. Вариации на тему «Мертвых душ» в славянской и западноевропейской литературе. С. $118-132$.

Кибальник С.А. Гоголь, Достоевский, славянский мир и «социальное христианство». С. 133-143. Крыстева Денка. Мирская канонизация Гоголя и идеологические нарративы середины XIX века. С. 144-154.

Судьбы произведений Гоголя в славянском мире:

Сартаков Е.В. Гоголь и сербская драматургия: «Подозрительная личность» Бранислава Нушича. С. $156-163$.

Вранеш Александра. О постановках гоголевских пьес в сербском театре. С. 164-167.

Няголова Наталия. Комедия Н.В. Гоголя «Ревизор» в болгарском театре начала XX века. C. $168-173$.

Чавдарова Дечка. Болгарская действительность, увиденная сквозь призму творчества Гоголя. C. $174-180$.

Кшицова Дануше. Произведения Н.В. Гоголя в музыкальном переложении Л. Яначека и Б. Мартину. С. 181-189.

Антанасиевич Ирина. Гоголевские темы в русском комиксе Королевства Югославия. С. 190-199.

Шливар Василиса. Экранизация В.А. Старевичем гоголевской повести «Ночь перед Рождеством». С. 200-205.

Сабо Бояна. Статьи о Гоголе в эмигрантском журнале «Русский архив». С. 206-212.

Биловески Владимир. Штрихи к портрету Зоры Есенской - переводчицы Гоголя. С. 213-218.

Сугай Л.А. Книга о Гоголе профессора А.В. Исаченко: текст и контекст эпохи. С. 219-226.

Прозоров В.В. Гоголевские темы в «Свитке» Н.И. Ульянова. С. 227-230.

Байич Лиляна. Творчество Гоголя в современном преподавании литературы в Сербии. С. 231-238. Яковлевич-Радунович Анна. Гоголевские мотивы в романе «Колыбельная для Лиры» М. Йовановича. С. 239-244.

Гоголь: жизнь и творчество:

Денисов В.Д. Романическое повествование о Малой России в раннем творчестве Н.В. Гоголя. C. 246-256.

Кривонос В.Ш. Мифология и антропология места в повести Н.В. Гоголя «Старосветские помещики». С. 257-263.

Капустин Н.В. Почему все-таки обиделся Иван Иванович? С. 264-272.

Милентиевич Лазарь. Мертвые души в «Петербургских повестях». С. 273-280.

Вранеш Бранко. Образ дьявола в произведениях Н.В. Гоголя и М.А. Булгакова. С. 281-286.

Карташов В.С. Доктор И. Фибинг, врач Гимназии высших наук в г. Нежине. С. 287-289.

Робинов О.Ю. Образы гоголевских персонажей в русской графике (о выставке «Повести «Вечеров на хуторе близ Диканьки» в иллюстрациях художников XX в. - из собрания московского Дома Гоголя»). С. 290-292.

Иллюстрации российских художников к произведениям Н.В. Гоголя. С. 293.

Сведения об авторах. С. 294-303.

Гоголь теперь выглядит так // Metro. M., 2017. 30 июня. С. 7, 12.

[31 августа в широкий прокат выйдет фильм «Гоголь. Начало» (режиссер Егор Баранов), который уже наделал много шума. Почему стоит его увидеть и чем этот проект удивителен, об этом мы поговорили с Евгением Стычкиным, исполнившим одну из главных ролей в проекте - следователя полиции села Диканька Бинха.] 
Голубков C.A. О судьбах гоголевской традиции в наше время // Наука и культура России / Самарский гос. ун-т путей сообщения. Самара, 2017. Т. 1. С. 143-145.

[Роман Владислава Отрошенко «Приложение к фотоальбому» (2007).]

Горбунова Д.О. Методика постижения старшеклассниками традиций Н.В. Гоголя в творчестве М.А. Булгакова // Язык как основа современного межкультурного взаимодействия: Материалы IV международной научно-практической конференции (Пенза, 28 ноября 2017 г.) / Пензенский гос. технологический ун-т; отв. ред. Д.Н. Жаткин, И.В. Куликова. Пенза, 2017. С. 178-185.

Городилова T.C. В. Розанов о роли Н. Гоголя в русской культуре // Наука сегодня: фундаментальные и прикладные исследования: Материалы международной научно-практической конференции (Вологда, 27 сентября 2017 г.): В 2 ч. Ч. 1 / Научный центр «Диспут». Вологда, 2017. С. 122-123.

Готовщева А.Г. «Встреча» с Наполеоном как биографический конструкт в русской культуpe // Гуманитарный акцент / Российский гос. гуманитарный ун-т. М., 2017. № 3. С. 111-125. [В частности, герои Гоголя о Наполеоне.]

Грехнёвские чтения: Литературное произведение в системе контекстов: Материалы международной научной конференции (Нижний Новгород, 23-25 апреля 2016 г.). Вып. 7 / Национальный исследовательский Нижегородский гос. ун-т им. Н.И. Лобачевского; отв. ред. И.С. Юхнова. Нижний Новгород, 2017. 312 с.

Из содерж.:

К 180-летию комедии Н.В. Гоголя «Ревизор». Лгуны, вруны и фантазеры в литературе:

Белоногова В.Ю. Иван Хлестаков против Криспина. Еще нечто по поводу «пушкинской подсказки». С. 6-12.

[Криспин из неосуществленного замысла А.С. Пушкина и гоголевский Хлестаков.]

Федоров М.Л. Спектакль «Ревизор» В.Э. Мейерхольда в полемике Демьяна Бедного с представителями русского зарубежья. С. $12-17$.

Высоикая В.В. Литературные реминисценции в повести Гоголя «Шинель». С. 208-211.

Канарская Е.И. Н.В. Гоголь как персонаж пьес Н.В. Коляды «Старосветские помещики» и «Мертвые души». С. 211-220.

Гуминский B.M. Русская литература путешествий в мировом историко-культурном контексте / Российская академия наук. Институт мировой литературы им. А.М. Горького. М.: ИМЛИ РАН, 2017. 608 с.

Из содерж.:

Русская «Одиссея» и русский Гомер (пространство и время). С. 353-395.

[«Мертвые души» Гоголя.]

К проблеме мифологизации исторического времени и пространства (Гоголь и 1812 год). С. 396-439. Путешествие Гоголя по Святой Земле в контексте развития паломнической литературы. С. 440-485. [Указ. имен.]

Гушкова Л.В. Функции кольцевого повтора с междометием ей-Богу в речи персонажей повестей Н.В. Гоголя // Рациональное и эмоциональное в русском языке: сб. трудов международной научной конференции, посвященной 85-летию проф. П.А. Леканта (Москва, 24-25 ноября 2017 г.) / Московский гос. областной ун-т, Историко-филологический институт; отв. ред. Н.Б. Самсонов. М., 2017. С. 39-41.

Демченко А.А. «Тщусь, сколько возможно, надышаться стариной» (Гоголь и саратовский фольклор) // Фольклор Большой Волги: сб. научных статей. М., 2017. С. 330-343. [Материалы конференции «Фольклор Большой Волги» (Саратов, 13-15 октября 2014 г.) / Государственный центр русского фольклора, Саратовский гос. ун-т им. Н.Г. Чернышевского и др.] [Анализ статьи некоего К., напечатанной в журнале «Отечественные Записки» (в ответ на просьбу Гоголя присылать материалы о поверьях и обычаях русской жизни) и содержащей поверья и народные песни крестьян Саратовской губернии.] 
Денисов В.Д. Герои Гоголя: национальное, типическое, особенное // Культура и текст / Алтайский гос. педагогический ун-т. Барнаул, 2017. № 3(30). С. 6-29.

[Характерология героев повести «Тарас Бульба» (1835).]

Денисов В.Д. Гоголевский именослов: о форме и семантике личных имен в повестях «Миргорода» // Проблемы исторической поэтики / Петрозаводский гос. ун-т; гл. ред. В.Н. Захаров. Петрозаводск, 2017. Т. 15. № 1. С. 38-54.

[Характеристика антропонимов в повестях цикла Гоголя «Миргород» (1835).]

Денисов В.Д. Историческая мифология в первой малороссийской повести Н.В. Гоголя «Вечер накануне Ивана Купала» // Проблемы исторической поэтики / Петрозаводский гос. ун-т; гл. ред. В.Н. Захаров. Петрозаводск, 2017. Т. 15. № 2. С. 7-23.

Джафарова К.К. Повествовательные жанры в «Учебной книге словесности для русского юношества» Н.В. Гоголя // Вестник Дагестанского гос. ун-та. Серия 2. Гуманитарные науки. Махачкала, 2017. Т. 32. № 4. С. 20-26.

[Жанр повести и проблема разграничения малых эпических форм (повести, рассказа, новеллы) в книге Гоголя.]

Дзюба Г.Е. Гоголь о девичьих смешинках и печалинках. М.: Палитра Д, 2017. 352 с. 1000 экз.

[Женские образы в «Вечерах на хуторе близ Диканьки».]

Дмитриева Е.E. Метонимия в повести Н.В. Гоголя «Невский проспект» // Печать и слово Санкт-Петербурга (Петербургские чтения - 2016): сб. научных трудов XVIII всероссийской научной конференции (Санкт-Петербург, 15-16 апреля 2016 г.): В 2 ч. Ч. 2: Литературоведение. Лингвистика / Санкт-Петербургский гос. ун-т промышленных технологий и дизайна; науч. ред. Н.Б. Лезуновой [и др.]. СПб., 2017. С. 296-300.

Дмитрина О.В., Мишустина (Дербина) Е.В. Специфика употребления украинизмов в повести Н.В. Гоголя «Тарас Бульба» // Семантико-когнитивные исследования: межвузовский сб. научных трудов. Вып. 8 / Министерство образования и науки Российской Федерации; Воронежский гос. ун-т; Центр коммуникативных исследований ВГУ; Ярославский гос. ун-т им. П.Г. Демидова; науч. ред. М.А. Стернин. Воронеж, 2017. С. 13-17.

Дни науки КФУ им. В.И. Вернадского: Материалы III научно-практической конференции профессорско-преподавательского состава, аспирантов, студентов и молодых ученых. Гуманитарно-педагогическая академия (Симферополь, 1-3 ноября 2017 г.). Т. 3 / Крымский федеральный ун-т им. В.И. Вернадского. Симферополь, 2017. 230 с.

Из содерж.:

Кухлевская А.Б. Контекстуальные антонимы в описании интерьера в поэме Н.В. Гоголя «Мертвые души». С. 117-118.

Музыченко И.В. Фольклорные мотивы в повести «Вечер накануне Ивана Купала». С. 118-120.

Долгушин Д.В. Тема Палестины в творческом диалоге В.А. Жуковского и Н.В. Гоголя // Вестник Новосибирского гос. ун-та. Серия История, филология. Новосибирск, 2017. Т. 16. № 2: Филология. С. 140-145.

Домбровский Ю.А. Болезнь. Последние годы жизни: роман. М.: Изд-во ИТРК, 2017. 112 с. - (Золотой век русской литературы).

[Роман посвящен Гоголю.]

Донецкие чтения 2017: Русский мир как цивилизационная основа научно-образовательного и культурного развития Донбасса: Материалы международной научной конференции студентов и молодых ученых. Посвящена 80-летию ДонНУ (Донецк, 17-20 октября 2017 г.). Т. 4: Филологические науки. Ч. 2: Языкознание, литературоведение, культурология, журналистика / Донецкий национальный ун-т; под общ. ред. С.В. Беспаловой. Донецк, 2017. 298 с.

Из содерж.: 
Коледа В.М., Ревяков И.С. Русский мир в поэме Н.В. Гоголя «Мертвые души». С. 189-190.

Семенова О.С., Кравченко О.А. Модернистская трансформация реалистической традиции (Н.В. Гоголь и Ф. Кафка). С. 216-218.

Дубовиикий В.В. Фантазм во фрейдовском и в эстетическом бессознательном // Философия и культура. М., 2017. № 5(113). С. 36-52.

[На примере повести Гоголя «Вий».]

Дубровская С.А. Бахтинская концепция смеха Н.В. Гоголя в социокультурном контексте 1940-50-х гг. // Проблема хронотопа в современных научных исследованиях: сб. докладов и статей / Институт художественного образования и культурологии Российской академии образования; ред.-сост., перевод, подгот. стенограмм Е.А. Семеновой. M., 2017. C. 270-279.

[Материалы международного круглого стола, посвященного М.М. Бахтину (Москва, 19-20 апреля 2017 г.).]

[Рецепция бахтинского сюжета «Гоголь и Рабле» в отечественной гуманитарной науке 1940 1950-х гг.]

Егорова С.О. Эсхатологические смыслы «Мертвых душ» Н.В. Гоголя // Известия Волгоградского гос. педагогического ун-та. Волгоград, 2017. № 4(117). С. 140-145.

Елфимова М. Ритмическая организация текста в повести Н.В. Гоголя «Тарас Бульба» // Stephanos. 2017. № 6(26). C. 189-196 (www.stephanos.ru).

Еремеева А.С. Смысл финала комедии Н. Гоголя «Ревизор» // Инновационное реформирование экономики и общества в условиях глобальной нестабильности: Материалы III международной научно-практической конференции (Саратов, 10 марта 2017 г.) / Поволжский институт управления им. П.А. Столыпина - филиал Российской академии народного хозяйства и государственной службы при Президенте РФ; отв. ред. И.В. Кузнецов. Саратов, 2017. С. 88-94.

Ершов А.Г. Характер использования эпистолярного материала в «Выбранных местах из переписки с друзьями» Н.В. Гоголя // Филологические науки. Вопросы теории и практики. Тамбов: Грамота, 2017. № 8-1(74). С. 21-24.

[Процесс трансформации частного письма в главу итогового произведения.]

Есаулов И.А. Русская классика: новое понимание. Изд. 3-е, испр. и доп. СПб.: Изд-во Русской Христианской гуманитарной академии, 2017. 550 с.

Пасхальность в поэтике Гоголя. С. 123-158.

Жигулина Н.А. Традиционные блюда русской кухни «каша» и «няня» в языке поэмы Н.В. Гоголя «Мертвые души» // Русский язык в диалоге культур: Материалы всероссийской научно-практической конференции (с международным участием) (Саранск, 6 июня 2017 г.) / Национальный исследовательский Мордовский гос. ун-т им. Н.П. Огарева; отв. ред. Ю.А. Мишанин. Саранск. 2017. С. 518-523.

[Значение и функционирование слов «каша» и «няня» в поэме Гоголя с точки зрения иностранного читателя.]

Жигулина Н.А., Чжан М. Традиционное русское блюдо щи в языке поэмы Н.В. Гоголя «Мертвые души» // Россия между модернизацией и архаизацией: 1917-2017 гг.: Материалы XX всероссийской научно-практической конференции (Екатеринбург, 11-12 апреля 2017 г.): В 2 т. Т. 1 / Гуманитарный ун-т. Екатеринбург, 2017. С. 454-457.

[Значение и функционирование лексемы «щи» в поэме Гоголя с точки зрения иностранного читателя.]

Жиркова М.А. Исповеди в романе Ф.М. Достоевского «Братья Карамазовы»: Учебное пособие / Ленинградский гос. ун-т им. А.С. Пушкина. СПб., 2017. 140 с.

Гл. 1: Генезис жанра литературной исповеди и его формирование.

5. К истории развития жанра: Августин, Руссо, Гоголь и Толстой. 
5.3. Исповедально-проповедническое начало «Выбранных мест из переписки с друзьями» Н.В. Гоголя. С. 39-44.

Жукова Л.Е. «Шкатулка» Александра Кушнера (некоторые размышления о стихотворении) // Текст культуры и культура текста: Материалы IV международного педагогического форума (Сочи, 16-17 октября 2017 г.) / Российское общество преподавателей русского языка и литературы, Общество русской словесности, Российская академия образования, Московский педагогический гос. ун-т [и др.]; редкол.: Л.А. Вербицкая, С.И. Богданов, О.Е. Дроздова [и др.]. СПб., 2017. С. 473-477.

[Гоголевские аллюзии (шкатулка Чичикова) в стихотворении А. Кушнера «Шкатулка».]

Журавлева A.B. Гоголь и Леонтьев: особенности русского эсхатологического мировосприятия // Гуманитарные ведомости Тульского гос. педагогического ун-та им. Л.Н. Толстого. Тула, 2017. № 2(22). С. 55-62.

[Сравнительный анализ эсхатологических воззрений Гоголя и К.Н. Леонтьева.]

Забудряева Ю.А. Мотив разрушения семьи и дома в творчестве Н.В. Гоголя // Littera terra: Материалы VI международной конференции молодых ученых (Екатеринбург, 1 декабря 2017 г.). Вып. 12 / Уральский гос. педагогический ун-т; гл. ред. И.А. Семухина. Екатеринбург, 2017. С. 133-139.

[На примере повестей «Старосветские помещики», «Майская ночь, или Утопленница» и поэмы «Мертвые души».]

Завгородний A.M. «Мертвые души» в полифонии французских интерпретаций // World Science: Problems and Innovations: сб. статей XV международной научно-практической конференции (Пенза, 30 ноября 2017 г.): В 4 ч. Ч. 3 / Отв. ред. Г.Ю. Гуляев. Пенза: Наука и Просвещение, 2017. С. 220-225.

Завгородний А.М. Поэма Н.В. Гоголя «Мертвые души» на французском: опыт одного перевода // Наука сегодня: проблемы и перспективы развития: Материалы международной научно-практической конференции (Вологда, 29 ноября 2017 г.): В 3 ч. Ч. 3. Вологда: ООО «Маркер», 2017. С. 12-15.

Завгородний A.M. Французская рецепция поэмы Н.В. Гоголя «Мертвые души» в эпоху франко-русского союза: начало XX в. // Филологические науки. Вопросы теории и практики. Тамбов, 2017. № 3(69): В 3 ч. Ч. 2. С. 26-31.

[Особенности восприятия поэмы «Мертвые души» во Франции в начале XX в. Первая французского диссертация по Гоголю Р. Тырневой. Обзор изданий, посвященных Гоголю и его произведению.]

Заграновская 3.В., Щенникова Н.В. Особенности перевода реалий на материале произведения Н.В. Гоголя «Тарас Бульба» // V Авдеевские чтения: сб. статей всероссийской научно-практической конференции преподавателей, учителей, аспирантов, магистрантов, студентов и школьников (Пенза, 5 апреля 2017 г.) / Пензенский гос. ун-т; ред. Ю.А. Шурыгина. Пенза, 2017. С. 42-45.

Зайцева Г.Н., Кипреева Н.И. Образ дороги в русской литературе и живописи XIX-XX веков (на материале поэмы Н.В. Гоголя «Мертвые души») // Развитие науки и техники: механизм выбора и реализации приоритетов: сб. статей международной научно-практической конференции (Екатеринбург, 15 июня 2017 г.): В 3 ч. Ч. 2 / Отв. ред. А.А. Сукиасян. Уфа, 2017. С. 46-49.

Звонникова Л. Изнанка шинели. О чем же на самом деле повесть Гоголя? // Фома: православный журнал для сомневающихся. М., 2017. № 2(166). Февраль. С. 66-72.

[Подгот. Виталий Каплан.]

[Повесть Гоголя «Шинель».] 
Зыкова Г.В., Недзвеикий В.А. История русской литературной критики XVIII-XIX веков: Учебное пособие для академического бакалавриата. Изд. 2-е, испр., доп. М.: Издво Юрайт, 2017. 304 с. - (Сер. Бакалавр и магистр. Модуль).

Лекция 9-10: Писательская критика 1820-х годов (А.С. Пушкин, Н.В. Гоголь). С. 94-120.

Зырянова О.Н. Рецепция Н.В. Гоголя в современной русской драме // Языки и литература в поликультурном пространстве / Алтайский гос. ун-т. Барнаул, 2017. № 3. С. 16-21. [Рецепция произведений Гоголя в пьесах Н. Коляды и О. Богаева.]

Иванникова И.Д., Мазуренко Н.Ю. Православный Гоголь // Молодежный инновационный вестник / Воронежский гос. медицинский ун-т им. Н.Н. Бурденко. Воронеж, 2017. Т. 6. № 3. Приложение 3. С. 75-76.

Иванова E.A. Мистические мотивы в романе О. Уайльда «Портрет Дориана Грея» и повести Н.В. Гоголя «Портрет» // Методы науки. Уфа, 2017. № 1. С. 66-67.

Иванова E.C. Функциональность гоголевских цитат в прозе М.А. Булгакова // Русская речь. М., 2017. № 2. С. 21-28.

Ивинский Д.П. Штейнер и «фигура фикции»: к интерпретации «Мастерства Гоголя» Андрея Белого // Арабески Андрея Белого: жизненный путь. Духовные искания. Поэтика: международная научная конференция, посвященная 135-летию со дня рождения Андрея Белого (Москва, Белград, 26-31 октября 2015 г.). Белград, 2017. С. 519-527.

Игнативосян Т.В. «Белые» и «черные» гении в повести Н.В. Гоголя «Портрет» (русско-зарубежные связи как способ интеграции в преподавании литературы в профессиональных образовательных учреждениях) // Интеграционные технологии в преподавании филологических дисциплин: сб. статей по материалам всероссийской научно-практической конференции (Нижний Новгород, 20-21 апреля 2017 г.) Вып. 8 / Нижегородский гос. педагогический ун-т им. Козьмы Минина; науч. ред. А.Л. Латухиной, Ж.И. Можновой. Нижний Новгород, 2017. С. 97-103.

Ильинская Т.Б., Федотова А.А. Повесть Н.С. Лескова «Заячий ремиз» в контексте прозы Н.В. Гоголя // Русская литература. СПб., 2017. № 3. С. 213-222.

Иноуэ Ю. Два контрастных знахаря в произведениях Н.В. Гоголя и перевод на японский язык предложений, включающих ритмико-звуковые приемы, ассоциируемые с их образами // Русский язык и культура в зеркале перевода / Высшая школа перевода (факультет) Московский гос. ун-т им. М.В. Ломоносова. М., 2017. № 1. С. 193-200.

[Сопоставлены два гоголевских персонажа: Пузатый Пацюк из повести «Ночь перед Рождеством» и доктор из повести «Нос», принявший коллежского асессора Ковалева.]

Историческая поэтика русской литературной классики (Гоголь - Лесков - Достоевский): научные труды молодых ученых / Российский гос. педагогический ун-т им. А.И. Герцена; ред. Е.И. Анненкова, Ю.В. Балакшина; сост., науч. ред. О.В. Евдокимовой. СПб., 2017. 150, [1] с.

Ершов А.Г. Экфрасис в концепции «Выбранных местах из переписки с друзьями» Н.В. Гоголя (на материале главы XXIII («Исторический живописец Иванов»). С. 5-15.

Исупов К.Г. О философской критике Серебряного века // EINAI: Проблемы философии и теологии / Санкт-Петербургский гос ун-т аэрокосмического приборостроения. СПб., 2017. Т. 6. № 1(11). С. 5-17.

[В частности, философы рубежа XIX-XX вв. о Гоголе.]

Кабаева Е.Д. Духовные истоки творчества Н.В. Гоголя // Язык и текст. 2017. Т. 4. № 2. C. 10-13. 
Кабаева Е.Д. Рим и католичество в духовной жизни Н.В. Гоголя // Утренняя заря: молодежный литературоведческий альманах / Ред.-сост. Т.А. Алпатова. Вып. VII: Литература в контексте межкультурного диалога. М., 2017. С. 13-17.

[Итальянский период жизни Гоголя, его религиозно-философские взгляды и интерес к католицизму в «римскую эпоху».]

Канарская Е.И. Двоемирие как архетип русской литературы и его воплощение в творчестве Н.В. Коляды // Вестник Нижегородского ун-та им. Н.И. Лобачевского. Нижний Новгород, 2017. № 3. С. 231-236.

[Рецепция Гоголя в драматургии Н.В. Коляды.]

Канарская Е.И. Образ Чичикова как связующее звено реального и ирреального миров в пьесах Н.В. Коляды «Коробочка» и «Мертвые души» // Дергачевские чтения - 2016. Русская словесность: диалог культурно-национальных традиций: Материалы XII всероссийской научной конференции: К 70-летию Объединенного музея писателей Урала (Екатеринбург, 13-14 октября 2016 г.) / Уральский федеральный ун-т им. первого Президента России Б.Н. Ельцина; Институт истории и археологии Уральского отделения Российской академии наук; Объединенный музей писателей Урала; отв. ред. О.В. Зырянов. Екатеринбург, 2017. С. 126-131.

Канарская Е.И. Элементы фольклорной традиции в образной системе «гоголевских» пьес Н. В. Коляды («Старосветские помещики», «Иван Федорович Шпонька и его тетушка», «Коробочка», «Мертвые души») // Русский язык в диалоге культур: Материалы всероссийской научно-практической конференции (с международным участием) (Саранск, 6 июня 2017 г.) / Национальный исследовательский Мордовский гос. ун-т им. Н.П. Огарева; отв. ред. Ю.А. Мишанин. Саранск, 2017. С. 539-544.

Капустина C.B. Повесть Н.В. Гоголя «Шинель» в восприятии крымских школьников // Русский язык в поликультурном мире: Материалы I международного симпозиума (Ялта, 8-12 июня 2017 г.). Т. 1 / Министерство образования, науки и молодежи Республики Крым; Крымский федеральный ун-т им. В.И. Вернадского; отв. ред. Е.Я. Титаренко. Симферополь, 2017. С. 153-158.

Капустина С.В. Проблема восприятия современными школьниками повести Н.В. Гоголя «Шинель» // Художественный текст глазами молодых: Материалы международной научно-практической конференции (Ярославль, 22 октября 2016 г.) / Ярославский гос. ун-т им. П.Г. Демидова; сост. Е.А. Федорова. Ярославль, 2017. С. 14-19.

Карандашова О.С., Логунов М.Л. К вопросу о художественном мышлении Н.В. Гоголя в «Миргороде» // Вестник Тверского гос. ун-та. Серия Филология. Тверь, 2017. № 3. С. 29-33.

Карташов В.С. Российские врачи в окружении А.С. Грибоедова, А.С. Пушкина, Н.В. Гоголя: Справочник. М.: Изд-во «Спутник+», 2017.91 с.

Николай Васильевич Гоголь (1809-1852). С. 65-90.

Карташов В.С., Исаева Е.В. Занятия Н.В. Гоголя итальянским языком. Диалог о растениях // Актуальные проблемы современной науки. М., 2017. № 2(93). С. 62-65.

Карташов В.С., Исаева Е.В. Растения в диалоге Н.В. Гоголя на итальянском языке // Естественные и технические науки. М., 2017. № 2(104). С. 11-12.

[Материалы занятий Гоголя иностранными языками, в частности, итальянским языком, сохранились в его бумагах в виде диалогов на разные темы. Один из диалогов, «В саду», посвящен растениям.]

Карташов В.С., Карташов А.В. Доктор А.И. Овер, лечащий врач Н.В. Гоголя // Актуальные проблемы современной науки. М., 2017. № 4(95). С. 154-155. 
Катермина В.В. Н.В. Гоголь и Ч. Диккенс как языковые личности русского и английского народов // Филологические науки в XXI веке: актуальность, многополярность, перспективы развития: сб. научных трудов / Кубанский гос. ун-т; под ред. В.И. Тхорика и др. Краснодар, 2017. С. 69-80.

Качис Л.Ф., Элиасберг Г.А. «Тарас» глазами «Янкеля»: Гоголь в еврейской и русско-еврейской литературе и критике второй половины XIX - начала XX в. // Общественные науки. М., 2017. № 4-1. С. 118-130.

[Рецепция Гоголя в творчестве еврейских литераторов 1860-1910-х гг., писавших на еврейских (идиш и иврит) и русском языках. Приводятся критические статьи рубежа XIX-XX вв., а также современные исследования, отражающие влияние Гоголя на еврейских писателей, включая Менделе Мойхер-Сфорима и Шолом-Алейхема. В своей полемике с русским классиком еврейские литераторы опирались на исторические хроники и свидетельства XVII-XVIII вв. о гибели еврейских общин Украины во время казацких восстаний, оставивших трагический след в коллективной памяти народа. Для нескольких поколений еврейской интеллигенции в России персонажи Гоголя служили важным аргументом в осмыслении поворотных вех русско-еврейской истории 1880-1910-х гг.]

Каширина В.В. «Лествица» в издании Оптиной Пустыни // Актуальные вопросы светской и духовной словесности. Вып. 1 / Российская академия наук. Институт мировой литературы им. А.М. Горького; редкол.: М.И. Щербакова (отв. ред.), О.А. Крашенинникова, Е.А. Осипова, Е.А. Самофалова. М.: ИПО «У Никитских ворот», 2017. С. 225-234. [О Гоголе: С. 232.]

Кибальник С.А. Гоголь, Достоевский и «социальное христианство» // Вопросы философии. М., 2017. № 4. С. 151-159.

Ким И.Е., Лю Я. Средства выражения приблизительного количества в поэме Н.В. Гоголя «Мертвые души» и ее китайском переводе // Вестник Новосибирского гос. ун-та. Серия История, филология. Новосибирск, 2017. Т. 16. № 2: Филология. С. 102-109.

Кирдянова Е.Р., Егорычева А.Д. Этнические традиции в современном российском кинематографе (на примере фильма «Вий» 2014 года) // Актуальные вопросы этнографии и этногеографии: сб. статей по материалам всероссийской студенческой научно-практической конференции (Нижний Новгород, 23 марта 2017 г.) / Нижегородский гос. педагогический ун-т им. Козьмы Минина. Нижний Новгород, 2017. С. 149-152.

[Этнические традиции казачества на примере повести Гоголя «Вий» и ее экранизаций 1967 и 2014 гг.]

Кияниченко А.Ю., Саськова Т.В. Мотив «живой»картины в «Овальном портрете» Эдгара По и в повести «Портрет» Н.В. Гоголя // Социально-гуманитарные проблемы образования и профессиональной самореализации. Социальный инженер-2017: сб. материалов всероссийской конференция молодых исследователей (Москва, 5-7 декабря 2017 г.). Ч. 4 / Московский гос. ун-т дизайна и технологии. М., 2017. С. 179-182.

Клинг O.A. Спор о «великом меланхолике» и роман Андрея Белого «Петербург» (Пушкин - Гоголь - Белый) // Новый филологический вестник. М., 2017. № 3(42). С. 137-148.

Ковалев Г.Ф. Истоки именника Н.В. Гоголя // Русская речь. М., 2017. № 2. С. 93-102. [Проблема биографизма творчества Гоголя; прототипы персонажей писателя.]

Ковалева В.С. Текстообразующая роль частиц в повести Н.В. Гоголя «Шинель» // Известия Смоленского гос. ун-та. Смоленск, 2017. № 4(40). С. 126-132.

Козлова Я.О. Календарный жанр в цикле Н.В. Гоголя «Вечера на хуторе близ Диканьки» // МНСК - 2017: Литературоведение: Материалы 55 международной научной студенческой конференции (Новосибирск, 16-20 апреля 2017 г.) / Новосибирский национальный исследовательский гос. ун-т. Новосибирск, 2017. С. 25-26. 
Колесниченко Д.А. Забытый «Тарас Бульба». Почему повесть Гоголя замалчивают для украинского читателя // Литературная газета. М., 2017. 13 июня. № 14. С. 1, 6-7.

Колмакова О.А., Ван Чжуаньчу. Орнаментальный сказ в «Повести о том, как поссорился Иван Иванович с Иваном Никифоровичем» Н.В. Гоголя // Вестник Бурятского гос. ун-та. Язык. Литература. Культура. Улан-Удэ, 2017. № 2. С. 48-53.

Колмакова О.А., Ван Чжуаньчу. Повесть Н.В. Гоголя «Вий» в русской литературе конца XX века: мотив бесовского вторжения в пьесе Н.П. Садур «Панночка» и рассказе Елизарова М.Ю. «Госпиталь» // Сюжетология и сюжетография / Институт филологии Сибирского отделения Российской академии наук. Новосибирск, 2017. № 2. С. 116-121.

Кондакова Ю.В. Категория имени в творческой судьбе Гоголя // Современная наука: актуальные проблемы теории и практики. Серия Гуманитарные науки. М., 2017. № 6. C. $153-157$.

Кондрашов А. Мент с Диканьки. Кинокартина «Гоголь. Начало» вышла на экраны страны // Литературная газета. М., 2017. № 35. С. 16.

Континуальность и дискретность в языке и речи: Материалы VI международной научной конференции (Краснодар, 24-28 октября 2017 г.) / Кубанский гос. ун-т; кафедра современного русского языка; отв. ред. Л.А. Исаева. Краснодар, 2017. 235 с.

Из содерж.:

Пономаренко И.Н., Мосьпан С.А. Средства формирования оценочной характеристики в прозе Н.В. Гоголя. С. $68-71$.

Белова А.В. Пространственные номинации как значимая часть языковой картины мира Н.В. Гоголя. С. $147-151$.

Короленко К.А., Петренко Т.С. Патография Н.В. Гоголя // Актуальные вопросы современной медицинской науки и здравоохранения: Материалы II международной (72 всероссийской) научно-практической конференции молодых ученых и студентов, II всероссийского форума медицинских и фармацевтических вузов «За качественное образование» (Екатеринбург, 12-14 апреля 2017 г.). Т. 2. Екатеринбург, 2017. С. 411-415.

[Гипотезы исследователей касательно предполагаемого психического расстройства Гоголя.]

Краснокутская С.Д. Пространственная лексика в цикле повестей Н.В. Гоголя «Миргород» // Гуманитарные научные исследования. М., 2017. № 6(70). С. 28.

Краснокутская С.Д. Языковые средства расширения и сужения пространства в повести Н.В. Гоголя «Вий» // European Research: Innovation in Science, Education and Technology: сб. статей по материалам XXXIV международной научно-практической конференции (Москва, 14-15 декабря 2017 г.). М., 2017. С. 50-52.

Кривонос В.Ш. Гоголевский слой в романе Д.С. Мережковского «Антихрист (Петр и Алексей)» // Известия Саратовского ун-та. Новая серия. Серия: Филология. Журналистика. Саратов, 2017. Т. 17. № 1. С. 70-74.

Кривонос В.Ш. Гоголь в русском литературном пространстве XIX-XX вв.: монография / Самарский гос. социально-педагогический ун-т. Самара: СГСПУ, 2017. 268 с.

Кривонос В. Универсалии в прозе Гоголя: монография. [Saarbrücken]: Palmarium Academic Publishing, 2017. 288 c.

Кривоус Т.В. О генезисе инфернального пространства в повести Н.В. Гоголя «Заколдованное место» // Литература и культура Дальнего Востока, Сибири и Восточного зарубежья. Проблемы межкультурной коммуникации: Материалы участников VII всероссийской научно-практической конференции с международным участием (Владиво- 
сток, 17 февраля 2017 г.) / Дальневосточный федеральный ун-т; отв. ред. А.А. Новикова. Владивосток, 2017. С. 77-80.

Кривоус Т.В. О специфике демонизации фольклорного образа знахаря-колдуна в повести О.М. Сомова «Русалка» и Н.В. Гоголя «Ночь перед Рождеством» // Наука в современном информационном обществе: Материалы XII международной научно-практической конференции (North Charleston, USA, 19-20 июня 2017 г.). 2017. С. 102-107.

Кривоус Т.В. Повесть Н.В. Гоголя «Заколдованное место»: мотив искушения в авторской концепции фантастического // Филологические открытия / Дальневосточный федеральный ун-т. Филиал ДВФУ в г. Уссурийске. Уссурийск 2017. № 5. С. 183-190.

Кривоус Т.В., Новикова А.А. Языковые маркеры инфернального пространства в повести Н.В. Гоголя «Пропавшая грамота» // Филологические науки. Вопросы теории и практики. Тамбов: Грамота, 2017. № 2-1(68). С. 31-33.

Кройчик Л.Е. Жизнь «под игом безумия» (история одной поездки) // Былое и мы: сб. научных статей / Воронежский гос. ун-т, факультет журналистики, кафедра истории журналистики; ред. С.Н. Гладышева. Воронеж, 2017. С. 80-103.

[В частности, о «Ревизоре» Гоголя.]

Крылова А.Г. Семантические особенности «говорящих» имен в художественном тексте // Вестник Московского гос. областного ун-та. Серия: Русская филология. М., 2017. № 1. C. 28-35.

[На примере произведений Гоголя и Ю.В. Буйды.]

Кублановский Ю.М. «Ослепительные клубы облаков...» [стихотворение] // Кублановский Ю. Долгая переправа. 2001-2017. М.: Б.С.Г.-Пресс, 2017. С. 226.

[О Гоголе.]

Курганов Е.Я. «Русский Мюнхгаузен»: Реконструкция одной книги, которая была в свое время создана, но так и не была записана. М.: Изд-во Б.С.Г.-Пресс, 2017. 224 с.

[Устные рассказы «русского Мюнхгаузена» - Д.Е. Цицианова, и их отражение в произведениях русских писателей, в том числе Гоголя.]

Курдюкова Д. Станиславского - в кабаре, Гоголя - на бульвар. Выставка «Скульптор Андреев. Кем вы были до 1917 года» открылась в Третьяковской галерее // Независимая газета. М., 2017. 25 сентября. С. 7.

Куренков А.С. Религиозно-философское осмысление святоотеческого наследия в литературном творчестве Н.В. Гоголя // Научные ведомости Белгородского гос. ун-та. Серия: Философия. Социология. Право. Белгород, 2017. № 10(259). С. 185-191.

Кушнерук С.П. Николай Васильевич бранится... (инвективы в гоголевском художественном тексте) // Коммуникативные аспекты современной лингвистики и лингводидактики: Материалы международной научной конференции (Волгоград, 9 января - 1 апреля 2017 г.) / Волгоградский гос. ун-т; отв. ред. А.В. Простов. Волгоград, 2017. С. 23-27. [Бранные речевые единицы как компоненты художественных произведений Гоголя.]

Ладыгина А.А. Специфика мотива письма в поздней прозе Н.В. Гоголя (на примере сборника «Выбранные места из переписки с друзьями») // Первые научные штудии (Новосибирск, 20 апреля 2017 г.). Вып. 7 / Новосибирский гос. педагогический ун-т; под ред. Е.Г. Николаевой. Новосибирск, 2017. С. 52-57.

Лазарев М. Идеальный раб. О бывших и настоящих Башмачкиных в оковах специализации // НГ-Ex libris. М., 2017. 14 сентября. С. 12.

Левитина В.Д. Поэма Н.В. Гоголя «Мертвые души» как история развития «души человеческой» // Фундаментальные проблемы науки: сб. статей международной науч- 
но-практической конференции (Казань, 20 июня 2017 г.): В 4 ч. Ч. 4 / Отв. ред. А.А. Сукиасян. Уфа, 2017. С. 85-89.

Либан Н.И. Русская литература: Лекции. Работы разных лет. Биографическое. Проза / Сост., подгот. текста Б.Н. Романова, В.М. Харламовой-Либан; коммент. Б.Н. Романова. М.: Водолей, 2017. 600 с.

Из содерж.:

В.Ф. Переверзев. С. 245-254.

[В.Ф. Переверзев О Гоголе.]

[Указ. имен.]

Люсый А.П. «Немец» и «итальянец»// Вестник Московского гос. лингвистического ун-та. М., 2017. № 1. С. 60-71.

[Образ Рима в одноименной повести и письмах Гоголя.]

Магомедалиева 3.Г., Малеикая Ж.В. Традиции и новаторство в романе Ф.М. Достоевского «Бедные люди» // Успехи современной науки и образования. Белгород, 2017. Т. 3. № 4. C. $118-120$.

[Гоголь («Шинель») и Ф.М. Достоевский («Бедные люди»).]

Мадякина T.B. Способы введения в произведения элементов мистического в русской литературе XIX века (на примере произведений Н.В. Гоголя) // Традиционная и инновационная наука: история, современное состояние, перспективы: сб. статей международной научно-практической конференции (Екатеринбург, 28 марта 2017 г.): В 2 ч. Ч. 2 / Отв. ред. А.А. Сукиасян. Уфа, 2017. С. 97-100.

Манн Ю.В. История русской литературы первой трети XIX века: учебник для академического бакалавриата. М.: Изд-во Юрайт, 2017. 441 с. - (Серия Бакалавр. Академический курс).

Гл. 14: «Сие к далекому стремленье». Романтическая коллизия на исторической и народной почве.

14. 5. Усложнение романтического мира в «Вечерах на хуторе близ Диканьки» Н.В. Гоголя. C. $317-322$.

Гл. 17: «Романтики открывают город».

17. 1. Метаморфоза романтического конфликта. С. 356-358.

[«Невский проспект» Гоголя.]

17. 2. Улица как художественный персонаж. С. 358-363.

[«Невский проспект» Гоголя.]

17. 3. Город в «Ревизоре» Н.В. Гоголя. С. 363-364.

17. 4. «Душевный город». С. 364-365.

[«Ревизор» Гоголя.]

Гл. 19: В силовом поле романтизма

19. 5. «Герой нашего времени» и «Мертвые души»: линия авторской судьбы. С. 403-405.

[Указ. имен.]

Манянина Е.И. Дом М.П. Погодина как культурно-исторический феномен, или Московское пристанище Н.В. Гоголя // Litera. 2017. № 4. С. 28-37 (e-notabene.ru/fil/article_24885.html).

Манянина Е.И. «Урок в музее» по произведению Н.В. Гоголя «Мертвые души» как практическое применение концепции «Гений места» // Litera. 2017. № 4. C. 21-27 (author. nbpublish.com/fil/article_24376.html).

$<$ Марков А.B> Книжная полка Александра Маркова // Новый мир. М., 2017. № 10. C. 204-212.

[Рец. на кн.: Видугирите И. Географическое воображение. Гоголь / [ил.: Гедрюс Йонайтис]. Vilnius: Vilnius Universitetas Petro ofsetas, 2015. 296 c.] 
Мартынова A.A. Материал для занятия в группе «Терапия творческим самовыражением М.Е. Бурно (ТТСБ)» по теме «Н.В. Гоголь» // Антология российской психотерапии и психологии: Материалы научно-практических конгрессов Общероссийской профессиональной психотерапевтической лиги и Национальной саморегулируемой организации «Союз психотерапевтов и психологов» (Москва, 12-15 октября 2017 г.); сетевое научно-практическое издание. Общероссийская профессиональная психотерапевтическая лига. Вып. 3 / Отв. ред. А.Е. Булычева. М., 2017. С. 184-185.

Маслова А.Г., Линь Сяолин. Характеристика сатирических образов комедии Н.В. Гоголя «Ревизор» в процессе изучения русского языка как иностранного // Advanced Science / Вятский гос. ун-т. Киров, 2017. № 1. С. 73.

Матлина С.Г. Музейная деятельность публичных библиотек итоги одноименной конференции в столичном «Доме Гоголя» // Библиотечное дело. СПб., 2017. № 22(304). С. 32-34.

Махлак К.А. Экклезиологические мотивы в творчестве Н. В. Гоголя // Acta Eruditorum / Русская христианская гуманитарная академия. СПб., 2017. № 22. С. 42-45.

[Образ Церкви в произведениях Гоголя.]

Медведева А.И. «Божественная комедия» Данте в диалоге с творчеством русских писателей (Н.В. Гоголь, Ф.М. Достоевский, М.А. Булгаков) // Молодой исследователь: вызовы и перспективы: сб. статей по материалам XXVIII международной научно-практической конференции (Москва, 27 февраля - 7 марта 2017 г.). № 3(28) / Отв. ред. Н.Р. Красовская. М., 2017. С. 57-61.

Меладшина Ю.В. Гоголевский «Ревизор» в контексте романа Владимира Шарова «Возвращение в Египет»// Вестник Пермского гос. гуманитарно-педагогического ун-та. Серия 3. Гуманитарные и общественные науки. Пермь, 2017. № 1. С. 83-92.

Меладиина Ю.В. Образы комедии Гоголя в судьбах героев и в сюжете романа В. Шарова «Возвращение в Египет» // Актуальные вопросы филологических наук: Материалы V международной научной конференции (Казань, 20-23 октября 2017 г.). Казань, 2017. С. 8-11.

[Герои «Ревизора» Гоголя в романе В. Шарова «Возвращение в Египет».]

Меладшина Ю.В. «Ревизор» в гоголевском тексте романа Владимира Шарова «Возвращение в Египет» // Вестник Удмуртского ун-та. Серия История и филология. Ижевск, 2017. T. 27. № 5. C. 693-706.

Мельман А. Дорогой мой Хлестаков! // Московский комсомолец. М., 2017. 25 мая. № 108. С. 6.

[Беседа с художественным руководителем московского театра «Et Cetera» А.А. Калягиным, сыгравшим Хлестакова в спектакле, поставленном режиссером Робертом Стуруа.]

Мельман А. Украинская комедия // Московский комсомолец. М., 2017. 30 июня. С. 10. [Гоголевские персонажи на политических ток-шоу российского телевидения.]

Мельник В.И. «Спасена буди вся земля...»: Московский блаженный Иван Яковлевич Корейша. М.: Храм преподобного Сергия Радонежского в Гольяново, 2017. 48 с.

[В частности, Гоголь и Иван Яковлевич Корейша.]

Мельникова Л.А. Мотив зеркала в романе Г. Бёлля «Групповой портрет с дамой» в контексте традиций Н.В. Гоголя // Культурология, искусствоведение и филология: современные взгляды и научные исследования: сб. статей по материалам IV международной научно-практической конференции (Москва, 17-27 октября 2017 г.). Т. 4(3) / Отв. ред. Е.Ю. Бутакова. М., 2017. С. 29-32.

Молодежь XXI века: образование, наука, инновации: Материалы VI всероссийской студенческой научно-практической конференции с международным участием (Ново- 
сибирск, 22-24 ноября 2017 г.) / Новосибирский гос. педагогический ун-т; отв. ред. А.Е. Козлов. Новосибирск, 2017. 265 с.

Из содерж.:

Букшану А.А. К вопросу о ценностной организации повести Н.В. Гоголя «Портрет» и новелл О. Бальзака. С. 9-10.

[Сопоставительный анализ фабул и сюжетов повести Гоголя «Портрет» и новелл Бальзка «Пьер Грассу», «Неведомый шедевр».]

Ладыгина А.А. Специфика героев-художников в произведениях Н.В. Гоголя. С. 22-25.

Монахова И. Только Гомер, Шекспир и Гоголь // Литературная Россия. М., 2017. № 34. С. 14.

Монин М.A. «Ревизор»: неоконченная пьеса на струнах расстояний // Credo New: теоретический журнал. СПб., 2017. №1. С. 142-173.

Муждабаева П.И. Просторечная лексика в повести Н.В. Гоголя «Заколдованное место» // Формирование профессиональной компетентности филолога в поликультурной образовательной среде: Материалы научно-практической конференции (Евпатория, 24-25 ноября 2017 г.) / Крымский федеральный ун-т им. В.И. Вернадского; под общ. ред. И.Б. Каменской. 2017. С. 146-150.

Муминов С.О. Изучение литературной комики Д.И. Фонвизина, А.С. Грибоедова и Н.В. Гоголя в школе: Учебное пособие. М.: ФЛИНТА: Наука, 2017. 112 с. Анализ комического начала в поэме Н.В. Гоголя «Мертвые души. С. 82-102.

Myрзина E.A. Язык прозы Н.В. Гоголя (на материале повести «Сорочинская ярмарка») // Амурский научный вестник / Амурский гуманитарно-педагогический гос. ун-т. Комсомольск-на-Амуре, 2017. № 3. С. 90-93.

Муртузалиева Е.А. Типология и жанр работы Д.С. Мережковского «Гоголь и черт» и образ Гоголя в ней // Вестник Северо-Восточного федерального ун-та им. М.К. Аммосова. Якутск, 2017. № 6(62). С. 96-104.

Мусатова Т.Л. Новая книга о Гоголе в Риме. Мир писателя, «духовно-дипломатические дела», эстетика, поиски социального служения (1837-1848). Материалы и исследования: В 2 т. Т. 1: В Риме (1837-1843). М.: ПРОБЕЛ-2000, 2017. 428 с. 300 экз.

[Рец.: Независимая газета. М., 2017. 10 августа. С. 9; Варламов С. Что прятал Гоголь. Автор «Мертвых душ» как эстет, закупщик и агент императора // Независимая газета. М., 2017. 17 августа. С. 15.]

Назировский архив: электронный журнал, посвященный наследию Р.Г Назирова. 2017. № 4(18).

Из содерж.:

Назиров Р.Г. О месте В. Ф. Одоевского в русской литературе. С. 9-55.

[В частности, князь В.Ф. Одоевский и Гоголь.]

Илюшин А.А. Отзыв о докторской диссертации Р.Г. Назирова «Традиции А.С. Пушкина и Н.В. Гоголя в русской литературе (опыт сравнительного исследования сюжетов и фабул)». С. 96-100.

Направления развития инструментов обеспечения экономической безопасности, методов анализа и аудита: Материалы 70 международной студенческой научно-практической конференции студентов, посвященной 125 -летию со дня рождения проф. Н.Д. Кондратьева (Москва, 14-17 марта 2017 г.) и Материалы международной научно-практической конференции «Информационное обеспечение экономической безопасности: проблемы и направления развития» (Москва, 17-18 апреля 2017 г.) / Российский гос. аграрный ун-т - Московская сельскохозяйственная академия им. К.А. Тимирязева; под ред. Н.Н. Карзаевой, Ю.Н. Каткова М.: «Научный консультант», 2017. 332 с.

Из содерж.:

Ламсков М.Г. Мошенничество в поэме Н.В. Гоголя «Мертвые души». С. 171-172.

Холопова В.С. Мошенничество в поэме Гоголя «Мертвые души». С. 189-192. 
Наука и творчество молодых исследователей: итоги и перспективы: Материалы II всероссийской студенческой научной конференции (Краснодар, 6 апреля 2017 г.) / Кубанский гос. ун-т; отв. ред. М.В. Шаройко и др. Краснодар, 2017. 230 с.

Из содерж.:

Агаджанова Т.С. «Душевная болезнь»: симптоматика по Гоголю. С. 64-67.

[Природа «душевной болезни», свойственной героям петербургских повестей Гоголя.]

Маликова Ю.В. Традиции Н.В. Гоголя в повести М.А. Булгакова «Похождения Чичикова. С. 114-117. Монастырная О.А. Феномен Н.В. Гоголя в эстетической концептологии В.В. Набокова. С. 118-121.

Немцев В.И. Формирование национального самосознания // Наука и культура России / Самарский гос. ун-т путей сообщения. Самара, 2017. Т. 1. С. 54-58.

[На примере поэмы Гоголя «Мертвые души».]

Нечаев А. Вечер на хуторе близ Сонной Лощины // Российская газета. М., 2017. 10 августа. С. 9.

[Сериалы штурмуют большой экран: премьера «Гоголя» пройдет в кинотеатрах. Интервью с режиссером фильма Егором Барановым.]

Нурмырадов Б.М. «Маленький человек» в произведениях Н.В. Гоголя // Инновационные технологии в науке нового времени: сб. статей по итогам международной научно-практической конференции (Казань, 12 июня 2017 г.) / Отв. ред. И.Н. Пилипчук. Уфа, 2017. С. 81-83.

Овсянникова A.A. Особенности передачи имен собственных при переводе с русского языка на украинский (на материале книги В. Мельниченко «Гоголевская Москва») // Вестник Московского гос. лингвистического ун-та. М., 2017. № 1. С. 48-59.

[Сложные случаи передачи имен собственных при переводе с русского языка на украинский, в авторской энциклопедии-хроноскопе В.Ю. Мельниченко «Гоголевская Москва» (Гоголівська Москва. Авторська енциклопедія-хроноскоп. М.: ОЛМА Медиа Групп, 2011. 831 с.: ил.).]

Овчинников Д.П. «Казалось, существование этого народа было вечно»: мифопоэтические пределы малороссийского текста русской литературы (к постановке проблемы) // Известия высших учебных заведений. Серия Гуманитарные науки / Ивановский гос. химико-технологический ун-т. Иваново, 2017. Т. 8. № 4. С. 324-327.

[Малороссия в творчестве Гоголя и В.Т. Нарежного.]

Овчинников Д.П. Малороссийский филэллинизм Н.В. Гоголя в повести «Старосветские помещики» // Филологические науки. Вопросы теории и практики. Тамбов, 2017. № 8-2(74). C. 42-45.

[Античный жанр идиллии в повести Гоголя.]

Овчинников Д.П. Хозяйственные взгляды Н.В. Гоголя // Шуйская сессия студентов, аспирантов, педагогов, молодых ученых: Материалы X международной научной конференции (Шуя, 8-9 июня 2017 г.) / Ивановский гос. ун-т, Шуйский филиал; отв. ред. А.А. Червова. Шуя, 2017. С. 185.

Огольцева E.B. Сравнение как языковой механизм гиперболы (на материале повестей Н.В. Гоголя) // Духовность и ментальность: экология языка и культуры на рубеже XXXXI веков: сб. статей по материалам международной научно-практической конференции, посвященной педагогической и научной деятельности проф. Г.В. Звёздовой и приуроченной к ее юбилею (Липецк, 21-22 марта 2017 г.) / Липецкий гос. педагогический ун-т им. П.П. Семенова-Тян-Шанского; отв. ред. И.П. Зайцева. Липецк, 2017. С. 110-117.

Огуриова В.С. Граница реального и ирреального в произведениях Н.В. Гоголя и В.И. Даля // Известия Саратовского ун-та. Новая серия. Серия: Филология. Журналистика. Саратов, 2017. Т. 17. № 4. С. 413-418. 
Океанский В.П., Океанская Ж.Л. «Мертвые души» между культурой и цивилизацией (к методике изучения названия гоголевской поэмы) // Научный поиск / Технологический центр. Шуя, 2017 № 4. С. 42-44.

Омеличкина Е.О. По Гоголю и не только [Рецензия] // Сцена. М., 2017. № 3(107). С. 14-15. [Рец. на спектакль Якутского ТЮЗа «Три ночи» (по мотивам повести Гоголя «Вий»). Преломление классического сюжета через призму национального якутского театра.]

Орлова О.В. Нравственный смысл комедии Н.В. Гоголя «Ревизор». IX класс // Литература в школе. М., 2017. № 3. С. 9-12.

Осипов Ю.И. Золотое сечение: Силуэты отечественной литературы. М.: ФЛИНТА, 2017. $320 \mathrm{c}$.

Портфель Гоголя. С. 6-19.

Осипчова T. «Вий». Первый фильм ужасов в СССР // Дарья. Биография. М., 2017. № 11. C. $8-9$.

Осьмухина О.Ю. Специфика воплощения мотива безумия в творчестве Э.Т.А. Гофмана и Н.В. Гоголя // Русско-зарубежные литературные связи: сб. статей по материалам VII всероссийской научно-практической конференции с международным участием (Нижний Новгород, 28-29 октября 2016 г.) / Нижегородский гос. педагогический ун-т им. К. Минина; науч. ред. Н.М. Ильченко. Нижний Новгород, 2017. С. 108-114.

Отечественная литература как фактор сохранения русской идентичности в глобальном мире: Материалы всероссийской научно-практической конференции (Самара, 18 мая 2017 г.) / Центр духовно-нравственного воспитания «Слово»; редкол.: Н.С. Филатова, Э.А. Радаева. Самара, 2017. 220 с.

Из содерж.:

Кривонос В.Ш. Место и сюжет в «Старосветских помещиках» Гоголя. С. 105-117.

Немцев В.И. Русская литература и общество как выразители эстетического идеала и социальной мысли. С. 132-152.

[В частности, на материале поэмы Гоголя «Мертвые души».]

Падерина Е.Г. О тяжбе по поводу «Тяжбы» и проблемах датирования хорошо запомнившегося современникам эпизода биографии Гоголя // Studia Litterarum. M., 2017. T. 2. № 2. C. $290-315$.

[О датировке окончательной редакции «Тяжбы» Гоголя, прочитанной автором в доме Аксаковых в первый приезд в Россию из-за границы (1839-1840 гг.)].

Пауткин А.А. Горизонты прочтения: Историко-филологические заметки и размышления. М.; СПб.: Нестор-История, 2017. 328 с.

Из содерж.:

Исторический роман Г. Сенкевича «Огнем и мечом» и русская литература. С. 236-250.

[Сопоставление романа Г. Сенкевича с «Тарасом Бульбой» Гоголя: С. 238.]

Петренко Н.А., Лагно В.В. «Движение» сатиры в изображении чиновничества в произведениях русских писателей (Н.В. Гоголь - М.Е. Салтыков-Щедрин - Л.Н. Толстой - М.А. Булгаков) // Human and Natural Sciences and Problems of Modern Communication: Materials of the I European International Research and Practice Conference (Prague, Czech Republic, 30 сентября 2017 г.) / Scientific Publishing Center «Open Knowledge». 2017. C. 68-77.

Петров В.Б. Булгаков и Гоголь: от философии к поэтике // Научные революции: сущность и роль в развитии науки и техники: сб. статей международной научно-практической конференции (Уфа, 28 августа 2017 г.): В 2 ч. Ч. 1. Уфа, 2017. С. 125-131.

Петрова М.В. Литературные архетипы в повестях Н.В.Гоголя // Известия Самарского научного центра Российской академии наук. Социальные, гуманитарные, медико-биологические науки. Самара, 2017. Т. 19. № 3. С. 97-100. 
[На материале петербургских повестей Гоголя.]

Петрова С.М. Графико-символическое пространство художественного текста в системе обучения русскому языку иностранцев // Вестник Российского ун-та дружбы народов. Серия Русский и иностранные языки и методика их преподавания. М., 2017. Т. 15. № 4. С. 414-426.

[На материале поэмы Гоголя «Мертвые души».]

Петрова Т.Г. [Реферат] // Социальные и гуманитарные науки. Отечественная и зарубежная литература. Серия 7: Литературоведение. Реферативный журнал. М.: РАН. ИНИОН, 2017. № 1. С. 53-58.

[Реф. кн.: Есаулов И.А. Постсоветские мифологии: структуры повседневности. М.: Академика, 2015. $616 \mathrm{c}$.

Петрова Т.Г. «Родина последняя, всё, чем Россия была и чем она будет»: русская классика в рецепции литературной критики эмиграции // Русское зарубежье: История и современность: сб. статей / РАН. ИНИОН. Центр сравнительного изучения цивилизаций; ред.-сост. Т.Г. Петрова, В.Г. Шаронова. М., 2017. С. 102-117.

[В частности, русская эмиграция о Гоголе.]

Плеханова Л.П. «Ироническое повествование» как средство выражения концептуальной информации в поэме Н.В. Гоголя «Мертвые души» // Слово. Предложение. Текст. Коммуникация: сб. научных трудов, посвященный памяти проф. А.И. Долгих / Липецкий гос. педагогический ун-т им. П.П. Семенова-Тян-Шанского; отв. ред. Е.А. Попова. Липецк, 2017. С. 171-179.

Поляков О.Ю. Джон Бэйли о «магическом реализме» Н.В. Гоголя // Зарубежные писатели о русской литературе: Материалы международной научной конференции «XIX Пуришевские чтения» (Москва, 5-7 апреля 2017 г.). М., 2017. С. 76-77.

Полякова А.С. Мотив зеркала в повести Н.В. Гоголя «Вий» // МНСК-2017: История и теория искусств: Материалы 55 международной научной студенческой конференции (Новосибирск, 17-20 апреля 2017 г.) / Новосибирский национальный исследовательский гос. ун-т Новосибирск, 2017. С. 77-78.

Потапчук В.И. Н.В. Гоголь в оценках отечественных философов // Основные тенденции государственного и общественного развития России: история и современность / Тихоокеанский гос. ун-т. Хабаровск, 2017. № 1. С. 7-17.

[В.В. Розанов, А.И. Введенский, Д.С. Мережковский, Н.А. Бердяев, А. Белый, И.А. Ильин, протоирей Г.В. Флоровский, протопресвитер В.В. Зеньковский и др.]

Про Пушкина и др.: Московские легенды, записанные Е.З. Барановым / Худ. В.И. Тихомиров. СПб.: Красный матрос, 2017. 32 с.

Пушкин и Гоголь. С. 10-18.

[Печ. по изд.: Московские легенды, записанные Евгением Барановым / Сост, вступ. статья и примеч. Веры Боковой; ред. Ю. Буртин. М.: Литература и политика, 1993.]

Проблемы взаимодействия языка, литературы и фольклора и современная культура: Материалы международной научно-практической конференции, посвященной памяти известных фольклористов - проф. Л.Г. Барага и доцента Л.И. Брянцевой (Уфа, 1-2 декабря 2016 г.) / Башкирский гос. ун-т, Собор русских Башкортостана; отв. ред. С.А. Салова. Уфа, 2017. 143 с.

Из содерж.:

Ахметова Г.А. Н.В. Гоголь в эстетической рецепции Л.Н. Толстого. С. 53-58.

Якубова Р.Х. Балаганные метаморфозы в поэме Н.В. Гоголя «Мертвые души». С. 112-120.

Проблемы исторической поэтики / Петрозаводский гос. ун-т; гл. ред. В.Н. Захаров. Петрозаводск, 2017. Т. 15. № 3.

Из содерж.: 
Виноградов И.А. Космополит или патриот? Концепция патриотизма в спорах с Гоголем и о Гоголе. С. 35-69.

[Гоголь в противостоянии славянофилов и западников.]

Кибальник C.A. «Христианский социализм» или «социальное христианство»? (Гоголь и Достоевский в истории русской социально-философской мысли. С. 70-93.

Шульи С.А. Трансформация инфернального в идиллическом: Н.В. Гоголь - Л.Н. Толстой И.А. Бунин. С. 158-178.

[На материале повестей Гоголя «Вий», Л.Н. Толстого «Дьявол», И.А. Бунина «Митина любовь».]

Радь Э.А., Сидорова И.А. Коннотации мотива «страсть» в общем семиотическом поле М.И. Цветаевой и Н.В. Гоголя // Новшества в области гуманитарных наук: сб. научных трудов по итогам международной научно-практической конференции (Тюмень, 25 декабря 2017 г.). Вып. 2. Тюмень: Федеральный центр науки и образования Эвенсис, 2017. С. 9-13.

Райкина М. Александр Калягин побил все рекорды... сыграв молодого Хлестакова // Московский комсомолец. М., 2017. 1 июня. № 114. С. 8.

[75-летний А.А. Калягин сыграл Хлестакова в спектакле «Ревизор. Версия» (режиссер Роберт Стуруа).]

Расев А.И., <протоиерей>. Очерк жизни в Бозе почившего Ржевского протоиерея о. Матфея Александровича Константиновского: Сводная редакция (1860-1890-1915) / [Вступ. статьи В. Воропаева; протоиерея А. Шабанова. Примеч. протоиерея А.И. Расева (в тексте)]. Тверь, 2017. 496 с.

Из содерж.:

Воропаев В. Оставаться на капитанском мостике до конца. Несколько слов о протоиерее Алексии Расеве и его книге. С. 12.

Шабанов А., протоиерей. Протоиерей Алексей Расев. In Memoriam. С. 13.

Щеглов И. Гоголь и о. Матвей Константиновский. С. 370-383.

[Впервые: Новое Время. 1901. 13 декабря. № 9260. С. 2-3. Загл.: Гоголь и о. Матвей Константиновский (История одного губительного недоразумения).]

Поселянин Е. Гоголь и прот. Матфей Ржевский. С. 384-388.

[Статья-реплика на статью И. Щеглова.]

[Впервые: Московские Ведомости. 1902. 27 февраля / 12 марта. № 57. Передовица.]

A.Н. <Александр Надеждин> Ржевский протоиерей Матфей Константиновский и отношение к нему Н.В. Гоголя. С. 389-395.

[Впервые: Православно-Русское Слово. 1902. Февраль. № 4. С. 275-293.]

Воспоминания прот. Феодора Образцова. С. 396-411.

Из воспоминаний Е.Н. Бастамовой. С. 429-431.

Суждение Д.С. Мережковского. С. 432-447.

Неизданное письмо о. Матфея Н.В. Гоголю. С. 458-460.

Известные письма странника-Гоголя о. Матфею. С. 461-470.

Введенский А.П., священник. Духовник Н.В. Гоголя. С. 478-488.

Ритм прозы от Карамзина до Чехова: монография / Министерство образования и науки Российской Федерации, Московский гос. лингвистический ун-т; под ред. Г.Н. Ивановой-Лукьяновой. М.: ФГБОУ ВО МГЛУ, 2017. 336 с.

Н.В. Гоголь. С. 93-128.

Природа и ритм в творчестве Н.В. Гоголя.

Ритм и смысл: Миргород», «Петербургские повести».

Портретные описания: Миргород», «Петербургские повести».

Ритмические портреты героев «Мертвых душ».

Ритм лирических отступлений в «Мертвых душах».

[2-е изд. М.: ФЛИНТА, 2019.]

Рогова A. Кошмары на хуторе близ Диканьки // Известия. М., 2017. 31 августа. С. 7. [Продюсер Александр Цекало и режиссер Егор Баранов представили зрителям многосерийный фильм «Гоголь. Начало». Его можно смело назвать самым зрелищным телевизионным российским проектом последних лет, что, собственно, и подвигло создателей на уникальный для на- 
шей киноиндустрии эксперимент - выпустить сериал, смонтировав его под формат кинотеатров, в широкий прокат.]

Роготнев И.Ю. Античная мениппея и «ложная сатира» в русской литературе // Филология в XXI веке: методы, проблемы, идеи: Материалы V всероссийской (с международным участием) научной конференции (Пермь, 10 апреля 2017 г.) / Пермский гос. национальный исследовательский ун-т; отв. ред. И.И. Русинова. Пермь, 2017. С. 333-342. [В частности, на материале «Записок сумасшедшего» Гоголя.]

Родионов Д.В. Пожалеть Гоголя или горький смех Дмитрия Крымова // Сцена. М., 2017. № 1(105). С. 15-18.

[Рец. на спектакль Лаборатории Дмитрия Крымова «Своими словами. Н. Гоголь «Мертвые души» (история подарка)». Особенности творческого метода режиссера, в котором ирония и гротеск соединяются с широким культурным контекстом.]

Норитейн Ю.Б. О земных и воздушных путях в искусстве / [беседу вел Дмитрий Родионов] // Сцена. 2017. № 1 (105). С. 3-7.

Розанов В.В. Избранные литературно-эстетические работы. М.: Изд-во Юрайт, 2017. 450 с. - (Антология мысли).

Пушкин и Гоголь. С. 192-202.

Как произошел тип Акакия Акакиевича. С. 202-214.

О сладчайшем Иисусе и горьких плодах мира. С. 386-396.

[В частности, Д.С. Мережковский о Гоголе].

Романенко Ю.М. Русский логос и малороссийский мифос: событие Николая Гоголя // Русский логос: горизонты осмысления: Материалы международной философской конференции (Санкт-Петербург, 25-28 сентября 2017 г.) / Санкт-Петербургский гос. технологический ин-т (Технический ун-т); Социологический институт Российской Академии наук; Российский гос. педагогический ун-т им. А.И. Герцена; Русская христианская гуманитарная академия: В 2 т. Т. 2. СПб., 2017. С. 98-100.

[Гоголевское наследие как онтологическое событие в истории восточного славянства.]

Русская классика: сб. статей к 85-летию научной деятельности члена-корреспондента РАН Н.Н. Скатова / Институт русской литературы (Пушкинский Дом) РАН; ред.-сост. А.П. Дмитриев и Ю.М. Прозоров. СПб.: ООО Изд-во «Росток», 2017. 664 с.: ил.

Из содерж.:

Анненкова Е.И. «Я возмужал среди печальных бурь...» (О теме духовного возмужания и формах его воплощения у Пушкина и Гоголя). С. 132-146.

Денисов В.Д. О героях первых петербургских повестей Н.В. Гоголя. С. 147-159.

Манн Ю.В. «Игроки» шагают по земле (Заметки комментатора). С. 160-165.

[О пьесе Гоголя «Игроки».]

Русская классика: pro et contra. Золотой век: антология / Сост. Л.В. Богатыревой, Н.Ю. Даниловой, Г.Е. Потаповой; вступ. статья Д.К. Богатырева, Л.В. Богатыревой; коммент. Н.Ю. Даниловой. СПб.: РХГА [Русская христианская гуманитарная академия], 2017. 1040 с. - (Русский Путь).

Из содерж.:

Аксаков К.С. Несколько слов о поэме Гоголя «Мертвые души». С. 142-148.

Гоголь Н.В. О лиризме наших поэтов. С. 169-179.

Гоголь Н.В. В чем же наконец существо русской поэзии и в чем ее особенность. С. 180-193.

Вяземский П.А. Языков и Гоголь. С. 199-212.

Белинский В.Г. Письмо Н.В. Гоголю. С. 213-221.

Гоголь Н.В. Письмо В.Г. Белинскому <Конец июля - начало августа 1847, Остенде>. С. 222-229. Коммент. С. 941-1035.

Русская классика: pro et contra. Серебряный век: антология / Русская христианская гуманитарная академия; сост. и вступ. статья Л.В. Богатыревой и К.Г. Исупова. СПб.: РХГА, 2017. 987 с. - (Русский Путь). 


\section{Из содерж.:}

Анненский И.Ф. Художественный идеализм Гоголя. С. 128-239.

Мережковский Д.С. Гоголь и черт <Фрагмент.> С. 240-339.

Белый А. Гоголь. С. 530-545.

Брюсов В.Я. Испепеленный. К характеристике Гоголя. С. 546-569.

Розанов В.В. Загадка Гоголя. С. 603-617.

Русь и Гоголь. С. 618-620.

Трубецкой Е.Н. Гоголь и Россия. С. 621-633.

Блок А.А. Дитя Гоголя. С. 634-637.

Русская литература XIX-XX веков: Учебное пособие для поступающих в вузы: В 2 т. Т. 1: Русская литература ХІХ века / Московский гос. ун-т им. М.В. Ломоносова. Филологический факультет; сост. и науч. ред. Б.С. Бугрова, М.М. Голубкова. 14-е изд. М.: Изд-во Московского ун-та, 2017. 544 с.

Скороспелова Е.Б., Голубков М.М., Красовский В.Е. Н.В. Гоголь. С. 220-264.

Рясов Д.Л. Образы немецких врачей в произведениях Ф.М. Достоевского: продолжение традиции Н.В. Гоголя // Междисциплинарные связи при изучении литературы: сб. научных трудов: Материалы VII международной научно-практической конференции (Саратов, 25-26 мая 2017 г.) / Саратовский национальный исследовательский гос. ун-т им. Н.Г. Чернышевского, Институт филологии и журналистики; под ред. Т.Д. Беловой, А.Л. Фокеева. Саратов, 2017. С. 52-57.

[Образы медиков немецкого происхождения из произведений Ф.М. Достоевского (Крестьян Иванович Рутеншпиц, доктор Герценштубе) и Гоголя (Христиан Иванович Гибнер).]

Савинков C.B. «Мое слово» и «слово без меня» в творческой биографии Гоголя // Феномен творческого кризиса / Министерство образования и науки Российской Федерации, Уральский федеральный ун-т им. первого Президента России Б.Н. Ельцина; ред. Т.А. Снигирева, А.В. Подчиненнов. Екатеринбург, 2017. С. 205-213.

Сартаков E.B. Гоголь и сербская литература XIX века: к постановке проблемы // Вестник славянских культур. М., 2017. Т. 43. С. 142-151.

Сартаков E.B. История первой постановки комедии Н.В. Гоголя «Ревизор» на сербской сцене // Славяноведение / Российская академия наук. М., 2017. № 6. С. 12-20.

[Первая постановка «Ревизора» в Белграде на сцене Национального театра в 1870 г. (на материале публикаций в сербской печати).]

Сарычев B.A. Метафизика русской литературы: избранные труды / Липецкий гос. педагогический ун-т им. П.П. Семенова-Тян-Шанского. Липецк, 2017. 311 с.

Из содерж.:

«Печать национальности»: метафизические основания творчества раннего Гоголя. С. 19-29.

«Русская Россия». Концепция «истинно-русского царства» в книге Н.В. Гоголя «Выбранные места из переписки с друзьями». С. 30-84.

Савчук И.П. Особенности легенд, составивших основу в повестях «Вечера на хуторе близ Диканьки» // Вестник Югорского гос. ун-та. Ханты-Мансийск, 2017. № 1-2(44). С. $29-33$.

Седина Д.Р. Концепт «мистика» В повести Н.В. Гоголя «Вий» // XVIII всероссийская научно-практическая конференция молодых ученых, аспирантов и студентов в г. Нерюнгри, с международным участием, посвященная 25-летию со дня образования Технического института (филиала) СВФУ (Нерюнгри, 30 марта-1 апреля 2017 г.) / Северо-Восточный федеральный университет им. М.К. Аммосова, Южно-Якутский научно-исследовательский центр Академии наук Республики Саха (Якутия): Материалы конференции. Секции 4-7. Нерюнгри, 2017. С. 401-405.

VII всероссийский фестиваль науки (Нижний Новгород, 4-5 октября 2017 г.): сб. докладов: В 2 т. Т. 2 / Нижегородский гос. архитектурно-строительный ун-т; отв. ред. А.А. Лапшин. Нижний Новгород, 2017. 497 с. 


\section{Из содерж.:}

Шевциова Д.М. Использование разноуровневых тестов при изучении повести Н.В. Гоголя «Шинель. С. 58-62.

Савельева Д.В., Шевиова Д.М. Причины неудач Чичикова - главного героя поэмы Н.В. Гоголя «Мертвые души». С. 292-296.

Шевченко А.В., Шевцова Д.М. Почему чиновники приняли Хлестакова за ревизора? (по комедии Н.В. Гоголя «Ревизор»). С. 298-301.

Семенова Е.В. «Соотечественники! страшно!...»: Н.В. Гоголь о судьбе России // Новая наука: Опыт, традиции, инновации. Уфа, 2017. Т. 3. № 4. С. 133-138.

Семиотика поведения и литературные стратегии: Лотмановские чтения - XXII / Pocсийский гос. гуманитарный ун-т; ред.-сост. М.С. Неклюдова, Е.П. Шумилова. М.: РГГУ, 2017. 429 c. - (Cep. Monumenta Humanitatis: Чтения ИВГИ [Институт высших гуманитарных исследований им. Е.М. Мелетинского] - ИВКА [Институт восточных культур и античности] - ЦТС Ф [Центр типологии и семиотики фольклора]; Вып. 3).

Из содерж.:

Дмитриева Е.E. Литературная биография Павла Ивановича Чичикова и жизненный текст Николая Васильевича Гоголя. С. 144-164.

Савинков С.В. Как развиться до русского человека и не превратиться в немца: об авторском поведении Н.В. Гоголя в 1840-е годы. С. 165-180.

Сидельникова Е.Г. Мотив сна в повести Н.В. Гоголя «Майская ночь, или Утопленница» // Культурные тренды современной России: от национальных истоков к культурным инновациям: сб. докладов V всероссийской (с международным участием) научно-практической конференции студентов, магистрантов, аспирантов и молодых учёных (Белгород, 14 апреля 2017 г.): В 3 т. Т. 3 / Белгородский гос. ин-т искусств и культуры; отв. ред. С.Н. Борисов, И.Е. Белогорцева, В.С. Игнатова, Е.В. Бронникова. Белгород, 2017. С. 215-217.

Сидорова Ю.Е. Комические персонажи в творчестве Н.В. Гоголя // Теоретические, методологические и прикладные вопросы науки и образования: Материалы научной конференции (Самара, 28 февраля 2017 г.) / Самарский гос. ин-т культуры; отв. ред. О.А. Подкопаев. Самара, 2017. С. 86-88.

Синцов Е.В. Универсальные приемы выстраивания образа маленького человека в произведениях Н.В. Гоголя (о нарративной стратегии и рецепции) // Ученые записки Казанского ун-та. Серия Гуманитарные науки. Казань, 2017. Т. 159. № 1. С. 121-137.

[На материале циклов «Вечера на хуторе близ Диканьки» и «Миргород», петербургских повестей, пьес «Женитьба» и «Ревизор», поэмы «Мертвые души».]

Синцова С.В. Фрагмент о Кифе Мокиевиче и Мокие Кифовиче в ассоциативно-смысловых контекстах «Мертвых душ» // Филология и культура / Казанский (Приволжский) федеральный университет. Казань, 2017. № 4(50). С. 180-184.

Скрипник A.B. Семантические особенности перевода реалий на английский язык (на материале повести «Сорочинская ярмарка» Н.В. Гоголя) // Семиотическое пространство языка. Синхрония и диахрония: Материалы международной научно-практической конференции (Новосибирск, 14-15 февраля 2017 г.) / Новосибирский гос. технический ун-т; под ред. А.И. Бочкарева, А.А. Гетман. Новосибирск, 2017. С. 243-261.

Славутин Е.И., Пимонов В.И. Как все-таки сделана «Шинель» Гоголя? // Известия Самарского научного центра Российской академии наук. Социальные, гуманитарные, медико-биологические науки. Самара, 2017. Т. 19. № 3. С. 116-120.

Смирнова И. Вот перешед чрез мост Кокушкин... // Труд. М., 2017. 15 сентября. С. 7. [Про этот мост в Санкт-Петербурге писали Гоголь, Лермонтов, Пушкин и Достоевский.]

Соколова В.Ф. Раннее творчество Гоголя и общеевропейская историко-философская мысль // Филологические науки. Вопросы теории и практики. Тамбов, 2017. № 3-3(69). С. 38-41. 
Соловьев Н.Н. Добчинский и Бобчинский в свете журнальной деятельности П.А. Вяземского: особенности поэтического осмысления образа // Студент и наука (гуманитарный цикл) - 2017: Материалы международной студенческой научно-практической конференции (Магнитогорск, 3-4 мая 2017 г.) / Магнитогорский гос. технический ун-т им. Г.И. Носова; отв. ред. А.С. Гаан. Магнитогорск, 2017. С. 69-72.

Страницы минувшего: отечественная публицистика XIX - начала XX века: [сб.] / [Сост. Г.С. Лапшиной]. Изд. 2-е, испр. и доп. М.: Аспект Пресс, 2017. 288 с.

Из содерж.:

Гоголь Н.В. «Выбранные места из переписки с друзьями» (1847). С. 53-58.

[Значение болезней; О том, что такое слово; Русский помещик.]

Чернышевский Н.Г. Из «Библиографии» (Современник. 1856. № 5). Записки о жизни Н.В. Гоголя. С. 97-98.

Чернышевский Н.Г. Из «Заметок о журналах» (Современник. 1856. № 2). $<$ О сочинениях Гоголя.> С. 98.

Стрельникова И. Николай Гоголь. Мифы и реальность // Караван историй. М., 2017. № 9. C. 144-153.

Судаков М.A. В.А. Панов: штрихи к портрету помещика-славянофила // Самарский научный вестник. Самара, 2017. Т. 6. № 2(19). С. 140-144.

[В частности, В.А. Панов и Гоголь.]

Сун Иньнань. Исследование творчества Н.В. Гоголя в Китае: литературоведческие школы и их методологические проблемы // Вестник Санкт-Петербургского гос. ун-та технологии и дизайна. СПб., 2017. № 2. С. 65-69.

Сун Иньнань. Н.В. Гоголь в критической прозе В.В. Розанова // Филологические науки: вопросы теории и практики. Тамбов, 2017. №7. Ч. 2. С. 37-39.

Сухих И.Н. Русская литература для всех: от Гоголя до Чехова. СПб.: Лениздат Книжная лаборатория, 2017. 496 с. - (Классное чтение!).

Николай Васильевич Гоголь (1809-1852). С. 5-78.

Гоголек: веселый меланхолик.

Новый Гоголь: непонятый пророк.

Основные даты жизни и творчества Н.В. Гоголя.

«Невский проспект» (1834).

Всемогущий Невский: люди как предметы.

Две судьбы: трагедия и анекдот.

Финал: город-призрак.

«Мертвые души» (1842).

Поэма: Гомер, Данте, Сервантес и Чичиков.

Первая страница: образ целого.

Герой: подлец-приобретатель или воскресшая душа?

Портреты: смех и страх.

Автор: лирик и пророк.

Стиль: слова и краски.

Миссия Гоголя: наследие и наследники.

Итоги: великий треугольник золотого века.

Сюй Цзыдун. От Н.В. Гоголя к Лу Синю и оперному либретто Цэн Ли и Го Вэньцзина // Культура и цивилизация. М., 2017. Т. 7. № 3 А. С. 356-364.

[История создания либретто оперы китайского композитора Го Вэньцзина «Дневник сумасшедшего» («Волк в деревне»). Анализ причин востребованности повести Гоголя «Записки сумасшедшего» и рассказа Лу Синя «Дневник сумасшедшего» в оперном искусстве конца XXв.] 
Сюй Цзыдун. Гоголеана в русской музыке XIX-XX веков // Политематический сетевой электронный научный журнал / Кубанского гос. аграрный ун-т им. И.Т. Трубилина. Краснодар, 2017. С. 965-985.

[Обзор произведений на сюжеты Гоголя в русской музыке.]

Таинство слова и образа: сб. материалов научно-богословской конференции, посвященной памяти проф. МДА М.М. Дунаева (Сергиев Посад, 30 сентября 2016 г.) / Московская духовная академия, кафедра филологии; отв. ред. В.М. Кириллин, священник Д. Барицкий, диакон С. Пантелеев. М.: Московская духовная академия, Орфограф, 2017. 304 с.: ил.

Из содерж.:

Boponaев B.A. М.М. Дунаев как историк русской литературы. Несколько предварительных замечаний. С. 13-21.

[В частности, о сознательной церковности Гоголя, которой не было почти ни у кого из русских писателей-классиков.]

Бурмистрова С.В. Гоголевский дискурс как способ самоописания в «Воспоминаниях» А.О. Смирновой-Россет. С. 124-133.

Таракин П.М. С.Т. Аксаков - читатель и критик Н.В. Гоголя // Славянские чтения 2017: сб. материалов международной научно-практической конференции (Стерлитамак, 16-18 мая 2017 г.) / Стерлитамакский филиал Башкирского гос. ун-та; отв. ред. Л.В. Климина. Стерлитамак, 2017. С. 237-240.

Тарасов Б.Н. Избранные труды: В 4 т. Т. 2: «Дело идет об истине... О России». Исторические воззрения русских мыслителей и писателей XIX века. СПб..: Алетейя, 2017. 418 c.

Тахо-Годи E. «Остроклювый нахохлился Гоголь...»: [стихотворение] // Звезда. СПб., 2017. № 3. С. 17.

[Отклик на стихотворение о Гоголе Ю. Кублановского, посвященного автору. См.: Кублановский Ю.М. «Ослепительные клубы облаков...» [стихотворение] // Литературная учеба. М., 2016. № 3. Май-июнь. С. 26-27.]

Ташлыкова М.Б., Буй Т.Х. Частные видовые значения русского глагола в зеркале вьетнамского языка (на материале перевода «Мертвых душ» Н.В. Гоголя) // Современные исследования социальных проблем. Красноярск, 2017. Т. 9. № 4-1. С. 312-333.

Тетиор А.Н. Скрытый смысл произведений Н.В. Гоголя? // Sciences of Europe. Прага, 2017. № 11-5(11). С. 71-78.

[Большинство персонажей Гоголя, говоря его словами, - «существователи, задавившие корою своей земности, ничтожного самодоволия высокое назначение человека». В этом, видимо, была скрытая цель произведений писателя - показать ничтожество «существователей». Здесь - возможные истоки односторонности его героев.]

Тетиор А.Н. Мир с позиций философии множественности: монография. М.: Издательский Дом «Академия Естествознания» (Пенза), 2017. 622 с.

Из содерж.:

Скрытый смысл произведений Н.В. Гоголя. С. 510-524.

Титова А.С. Особенности функционирования прецедентных имен, восходящих к тексту поэмы Н.В. Гоголя «Мертвые души» (на примере прецедентного имени «Плюшкин») // Язык и культура региона как составляющие образовательного пространства: Материалы II международной научно-практической конференции (Белгород, 18-20 мая 2017 г.) / Белгородский гос. национальный исследовательский ун-т; отв. ред. Т.Ф. Новикова. Белгород, 2017. С. 194-197.

Тихонова Ю.В. Урок литературы в 7 классе на тему «здесь дьявол с Богом борются...»: тема борьбы за душу человека в повести Н.В. Гоголя «Вий» // Научные труды молодых ученых-филологов: Материалы всероссийской научно-методической конференции, посвященной 215-летнему юбилею В.И. Даля - Казака Луганского. T. XVI / Науч. ред. И.Г. Минераловой. Ярославль, 2017. С. 235-240. 
[Конференция «Филологическая наука в XXI веке: взгляд молодых» (Москва, 18-21 октября 2016 г.) / Московский педагогический гос. ун-т. Институт филологии.]

Токарева М. Прожженные души. Смешной и горький Гоголь на сцене «Мастерской Петра Фоменко» // Новая газета. М., 2017. № 71. С. 23.

Толстогузов П.Н. Муха в гоголевском тексте // Вестник Приамурского гос. ун-та им. Шолом-Алейхема. Биробиджан, 2017. № 1(26). С. 121-125.

[На материале поэмы «Мертвые души».]

Торшилов Д.О. Неизвестный перевод Андрея Белого // Литературный факт: научный журнал. М.: ИМЛИ РАН, 2017. Т. 4. С. 225-232.

[Перевод с французского языка статьи К. Зервоса (отзыв о постановке В.Э. Мейерхольдом «Ревизора» Гоголя).]

Тюленев А.И. Образ формально-рационального предпринимательства в поэме Н.В. Гоголя «Мертвые души» // Духовная сфера общества / Марийский гос. ун-т. Йошкар-Ола, 2017. № 14. С. 96-103.

Тынянов Ю.Н. История литературы. Поэтика. Избранные труды. М.: Изд-во Юрайт, 2017. 353 с. - (Сер. Антология мысли).

Из содерж.:

Достоевский и Гоголь (к теории пародии). С. 186-214.

Умурзакова А.М. Темный мир в цикле Н.В. Гоголя «Вечера на хуторе близ Диканьки» // Научное и образовательное пространство: перспективы развития: сб. материалов V международной научно-практической конференции (Чебоксары, 15 апреля 2017 г.) / Чувашский гос. ун-т им. И.Н. Ульянова [и др.]; редкол.: О.Н. Широков [и др.]. Чебоксары, 2017. С. 209-213.

Фаритов В.Т. Семиотика трансгрессии: Ю.М. Лотман как литературовед и философ // Вестник Томского гос. ун-та. Томск, 2017. № 419. С. 60-66.

Трансгрессия в художественной прозе Н.В. Гоголя. С. 62-64.

Федоренко Н.Г. Диалектные агнонимы в повести Н.В. Гоголя «Тарас Бульба» // Молодая филология - 2017 (по материалам исследований молодых ученых) (Новосибирск, 23-25 мая 2017 г. ): межвузовский сб. научных трудов: В 2 ч. Ч. 1 / Новосибирский гос. педагогический ун-т. Новосибирск, 2017. С. 167-172.

Федоров A.B. Алексей Константинович Толстой и русская литература его времени. М.: Русское слово, 2017. 752 с.

[Указ. имен.]

Федосеенко Н.Г., Капрелова М.Б., Круглов Р.Г. Литература и кинематограф: проблемы диалога искусств: коллективная монография / Министерство культуры Российской Федерации; Санкт-Петербургский гос. ин-т кино и телевидения. СПб., 2017. 199 с.

Русская классика на экране.

[В частности, рассмотрены экранизации произведений Гоголя.]

Федотова A.A. Лексико-семантические группы обозначений ужасного в языке повестей Н.В. Гоголя («Вий», «Портрет») // Евразийский научный журнал. Курск, 2017. № 1. C. 196-198.

Филологические этюды: сб. научных статей молодых ученых: В 3 ч. Ч. 1-3. Вып. 20. Саратов, 2017. 416 с.

[Материалы всероссийской научной конференции «Филология и журналистика в XXI веке» (Саратов, 26-28 апреля 2016 г.) / Саратовский национальный исследовательский гос. ун-т им. Н.Г. Чернышевского.]

Из содерж.:

Чепухова Е.M. Проблема границы в повести Н.В. Гоголя «Тарас Бульба». С. 15-18. 
[Оппозиция свое / чужое пространство; дифференцирующая функция границы на примере образов Андрия и Остапа.]

Рясов Д.Л. Н.В. Гоголь и Э.Т.А. Гофман: к вопросу о параллелях. С. 18-21.

Волоконская Т.А. Поэтика заглавия сборника Н.В. Гоголя «Арабески. С. 22-26.

Исаев М.П. «Обломовская душа» в художественном мире Гоголя. С. 132-136.

[Роман И.А. Гончарова «Обломов» и «повесть Гоголя «Старосветские помещики».]

Фомичев С.А. Повесть Н.В. Гоголя «Нос»: реальность абсурда // Русская литература. СПб., 2017. № 3. С. 189-196.

Фридрих Гёльдерлин и идея Европы: коллективная монография по материалам IV международной конференции по компаративным исследованиям национальных языков и культур / Под ред. С.Л. Фокина.. СПб.: Платоновское философское общество, 2017. 427 с. 300 экз.

Ч. 2. Гл. 5: Лысаков П.В. Европа, Италия, Гоголь: Рим и «Рим». С. 274-285.

Фролова А.Г. Социально-историческое и общечеловеческое в героях Н.В. Гоголя // Молодой ученый. Казань, 2017. № 1(135). С. 556-559.

Хворова O.B. Предметный мир в «Петербургских повестях» Н.В. Гоголя: семантика цвета // Российская наука в условиях реформ: практический результат инновационных трансформаций: сб. научных статей. Вып. 3. Тюмень, 2017. С. 20-25.

Хвостова О.С. Облик персонажей через их отношение к еде в поэме Н.В. Гоголя «Мертвые души» // Исследования и разработки: перспективные научные направления и результаты: сб. научных трудов. Вып. 1 / Ред. С.С. Чернов. Новосибирск, 2017. С. 77-88.

Холкина A.C. «Мертвые души» на английском языке: особенности передачи реалий в первых переводах // Актуальные вопросы филологической науки XXI века: сб. статей VI международной научной конференции молодых ученых (Екатеринбург, 10 февраля 2017 г.). Ч. 1: Современные лингвистические исследования / Министерство образования и науки Российской Федерации, Уральский федеральный ун-т им. первого Президента России Б.Н. Ельцина, Институт социальных и политических наук; под общ. ред. Ж.А. Храмушиной [и др.] Екатеринбург, 2017. С. 175-179.

Холондович Е.Н. Духовные основы гениальности // Вестник Православного Свято-Тихоновского гуманитарного ун-та. Серия 4. Педагогика. Психология. М., 2017. № 47. С. 135-146. [На примере творчества Гоголя и Ф.М. Достоевского.]

Холондович E.Н. Личность гения как предмет психолого-исторического исследования // Вестник Ун-та Российской академии образования. М., 2017. № 5. С. 51-60.

[Реконструкция жизненного пути и творческой биографии Гоголя.]

Хохлова E.A. Особенности использования творительного сравнительного в поэме Н.В. Гоголя «Мертвые души» // Языковая политика и вопросы гуманитарного образования: Материалы II международной научно-практической конференции (Пенза, 26-28 октября 2017 г.) / Пензенский гос. ун-т; под ред. Г.И. Канакиной, И.Г. Родионовой. Пенза, 2017. С. 210-214.

Христианство и русская литература: сб. восьмой / Отв. ред. В.А. Котельников и О.Л. Фетисенко. СПб.: Изд-во Пушкинский Дом, 2017. 628 с.: [12] с. вклейки.

Из содерж.:

Савельева М.Ю. Мифологические аспекты мышления Н.В. Гоголя. Миф личности (исходные установки). С. 26-67.

Хондзинский П.А., протоиерей. Н.В. Гоголь как представитель Laientheologie. С. 68-86.

[Указ. имен.]

Хуснутдинов А.А. Словарь языка комедии Гоголя «Ревизор» и проблемы авторской лексикографии // Русский язык в школе. М., 2017. № 4. С. 65-69.

[Рец. на кн.: Илюшина Л.А., Кимягарова Р.С., Баш Л.М. Словарь языка комедии Гоголя «Ревизор» / Ред. Т.Л. Беркович. М.: МАКС Пресс, 2016. 808 с.] 
Цветков E.A. Чжуан-цзы и Гоголь // Научная сессия КГТУ [Казанский гос. технологический ун-т]. Аннотация сообщений (5-8 февраля 2017 г.). Казань: КГТУ, 2017.

Цветкова В. На хуторе близ Диканьки готический замок и обнаженные девы: Журналисты на съемках самого амбициозного проекта года - сериала «Гоголь» // Независимая газета. М., 2017. 2 мая. С. 7.

Циманович Л.С. «Горный венец» П.П. Негоша и «Тарас Бульба» Н.В. Гоголя в контексте славянского романтизма // Славянские языки и культура. История и современность: Материалы международной научно-практической конференции (Санкт-Петербург, 27 апреля 2016 г.) / Ленинградский гос. ун-т им. А.С. Пушкина: отв. ред. Т.Е. Лебедева. СПб., 2017. С. 9-14.

Чаусова И.А. Анализ произведений русской классической литературы XIX века: Учебное пособие. М.: КДУ, Университетская книга, 2017. 322 с. - (Учебники и учебные пособия МГУ им. М.В. Ломоносова).

Н.В. Гоголь. С. 168-210.

[Ревизор, Шинель, Мертвые души.]

Чун Ен. Хо. Роль украинских мотивов в произведениях Гоголя // Вестник Красноярского гос. педагогического ун-та им. В.П. Астафьева. Красноярск, 2017. № 1(39). С. 159-162.

Шанурина М.Е. Шинель и бриллианты // Известия Смоленского гос. ун-та. Смоленск, 2017. № 3(39). C. 44-55.

[Повесть Гоголя «Шинель» как один из претекстов романа И. Ильфа и Е. Петрова «Двенадцать стульев».]

Шаньшань Ц., Казакова Ю.В. Колористический образ степи в произведениях русских классиков // Молодой исследователь: Материалы 4-й научной выставки-конференции научно-технических и творческих работ студентов (Челябинск, 18-19 апреля 2017 г.) / Министерство образования и науки Российской Федерации; Южно-Уральский гос. ун-т. Челябинск, 2017. С. 184-188.

[На материале повестей «Тарас Бульба» Гоголя и «Степь» А.П. Чехова.]

Шеваров Д. Книга - это шпага XXI века. В этом убежден художник и поэт Николай Предеин // Российская газета. М., 2017. 20 июля. С. 24.

Шевченко И. Последний дом // Русский мир. М., 2017. № 8. С. 72-79.

[Дом графов Толстых в Москве на Никитском бульваре, где жил последние годы Гоголь.]

Школьникова О.Ю., Дементьева А.В. Бежать или лететь стрелой: лексика движения в повести Н.В. Гоголя «Невский проспект» и ее итальянском переводе // Вестник Российского ун-та дружбы народов. Серия Теория языка. Семиотика. Семантика. М., 2017. T. 8. № 4. С. 811-825.

Шульи С.А. Гоголь и Флобер: «Вий» и «Госпожа Бовари» // Вопросы литературы. М., 2017. № 5. C. 319-327.

Шульи С.A. Интертексты образа «благородного разбойника» в «Мертвых душах» (Гоголь - Плутарх - Стендаль и др.) // Развитие гуманитарной науки в регионах России: Материалы международной научной конференции, посвященной 85-летию Института истории, языка и литературы Уфимского научного центра РАН (Уфа, 1-4 июня 2017 г.) / Сост. И.И. Буляков, Г.Б. Азаматова [и др.] Уфа: ИИЯЛ УНЦ РАН, 2017. С. 308-309.

Шульи С.A. К вопросу о традициях гомеровской «Одиссеи» в «Мертвых душах» Гоголя // Вестник Северо-Восточного федерального ун-та им. М.К. Аммосова: Серия Эпосоведение. Якутск, 2017. № 3(7). С. 52-56 (epossvfu.ru/wp-content/uploads/2017/09/pdf). 
Шульи C.A. Мотивы русской волшебной и бытовой сказки в повести Гоголя «Вий» // Wiener Slawistischer Almanach. Frankfurt am Main [и др.], 2017. Bd. 79. С. 155-164.

Шульи С.А. Поэма Гоголя «Мертвые души»: внутренний мир и литературно-философские контексты. СПб.: Алетейя, 2017. 288 с.

[Рец.: Осиповский O.E. // Вопросы литературы. М., 2019. № 1. С. 276-279.]

Шульи С.А. Пушкин - Гоголь - Л. Толстой («Барышня-крестьянка» - «Вий» - «Дьявол») // Восток - Запад в пространстве русской литературы и фольклора. Волгоград, 2017. C. 231-237.

Шульи С.А. «Тарас Бульба» Н.В. Гоголя и «Хаджи-Мурат» Л.Н. Толстого (аспект историософии, исторической поэтики и интертекстуальности) // Studia Slavica Academiae Scientiarum Hungaricae. 2017. T. 62. № 2. C. 419-445.

Шульи С. Хома Брут и Франсуа Вийон // Человек. М., 2017. № 2. С. 144-154.

Щеголева И.А. В поисках души. Поэма Н.В. Гоголя «Мертвые души»: опыт интертекстуального анализа. Статья третья // Литература в школе. М., 2017. № 4. С. 29-34.

Щеголева И.А. В поисках души. Поэма Н.В.Гоголя «Мертвые души»: опыт интертекстуального анализа. Статья четвертая // Литература в школе. М., 2017. № 8. С. 28-33.

Щербаков А.Б. Взгляд Гоголя на русскую литературу: мотив кастальского ключа // Концепции устойчивого развития науки в современных условиях: сб. статей по итогам международной научно-практической конференции (Казань, 14 декабря 2017 г.): В 6 ч. Ч. 4 / Отв. ред. А.А. Сукиасян. Уфа, 2017. С. 198.

[Осмысление Гоголем двух традиций - античной и христианской. Первая представлена скрытым мотивом кастальского ключа, а вторая - лейтмотивом ключа «самородного».]

Щербаков А.Б. Взгляд Гоголя на самобытность русской литературы: методологический аспект // Инструменты и механизмы современного инновационного развития: сб. статей международной научно-практической конференции (Пермь, 5 декабря 2017 г.): В 5 ч. Ч. 2 / Отв. ред. А.А. Сукиасян. Уфа, 2017. С. 202-205.

Щербаков А.Б. К.С. Аксаков о «сферах» поэзии // Современные проблемы и перспективные направления инновационного развития науки: сб. статей по итогам международной научно-практической конференции (Оренбург, 24 декабря 2017 г.): В 6 ч. Ч. 6 / Отв. ред. А.А. Сукиасян. Уфа, 2017. С. 216-217.

[В частности, К.С. Аксаков о Гоголе.]

Щербаков А.Б. Рефлективная поэтика Гоголя: понятие «самородного ключа» // Интеграционные процессы в науке в современных условиях: сб. статей международной научно-практической конференции (Казань, 3 декабря 2017 г.): В 3 ч. Ч. 3 / Отв. ред. А.А. Сукиасян. Уфа, 2017. С. 44-46.

[Понятие «самородного ключа» в гоголевской концепции самобытности русской литературы.]

Эмирова Л.А. «Всякая чертовщина», или фантастика в «петербургских» и «непетербургских» текстах Н.В. Гоголя и А.А. Бестужева // Известия Дагестанского государственного педагогического университета. Общественные и гуманитарные науки. 2017. T. 11. № 3. C. 105-111.

Этингоф O.E. Владикавказ и Москва в биографии и творчестве М.А. Булгакова. 2-е изд. М.: Издательский Дом ЯСК: Языки славянской культуры, 2017. 448 с.

[Указ. имен.]

Явари Ю.В. Реалии и локализмы в повестях Н.В. Гоголя // Вестник Тверского гос. технического ун-та. Серия Науки об обществе и гуманитарные науки. Тверь, 2017. № 3. С. 155-159. 
[На материале повестей Гоголя «Сорочинская ярмарка», «Майская ночь, или Утопленница», «Вечер накануне Ивана Купалы» и «Ночь перед Рождеством».]

Яровой С. «Тарас Бульба» Н.В. Гоголя: опыты экранизаций // Stephanos. 2017. № 6(26). C. 203-211 (www.stephanos.ru).

Яськевич И.Г. Записки сумасшедших в современной российской опере. Либретто логический аспект // Вестник музыкальной науки / Новосибирская гос. консерватория им. М.И. Глинки. Новосибирск, 2017. № 2 (16). С. 23-28.

[В частности, на материале оперы «Дня не было, числа тоже...» А. Кротова (по повести «Записки сумасшедшего» Гоголя).]

Яикив E.O. Мотив дьявольского искушения в «Ночи перед Рождеством» Н.В. Гоголя, или «Не так страшен черт, як його малюють» // Пасхальные чтения: Материалы четырнадцатой межвузовской научно-методической конференции. Ярославль, 2017. С. 35-40.

[Конференция «Гуманитарные науки и православная культура» (Москва, 5-6 мая 2016 г.) / Московский педагогический гос. ун-т, Институт филологии.]

\section{А В Т О Р ЕФ Е РАТ Ы}

Али Фарис Хассун Али. Синестезийная метафора в русской классической прозе: Автореф. дис. ... канд. филол. наук / Воронежский гос. ун-т. Воронеж, 2017. 19 с.: табл. Гл. 2: Синестезийная метафора в творчестве Н.В. Гоголя. С. 10-13.

Болотникова О.Н. Семантика и функции двери и окна в художественном мире Н.В. Гоголя: Автореф. дис. ... канд. филол. наук / Национальный исследовательский Томский гос. ун-т. Томск, 2017. 23 с.

Булатая E.B. Ирония как имплицитная форма выражения авторской модальности в художественном тексте: на материале произведений Н.В. Гоголя и их немецкоязычного перевода: Автореф. дис. ... канд. филол. наук / Балтийский гос. федеральный ун-т им. И. Канта. Калининград, 2017. 23 с.

Гончарова Н.В. Библиотека А.В. Никитенко как репрезентант его творческой и профессиональной деятельности: Автореф. дис. ... канд. филол. наук / Национальный исследовательский Томский гос. ун-т. Томск, 2017. 23 с.

Гл. 2: А.В. Никитенко - критик, профессор словесности и цензор в историко-литературном процессе 1830-1870-х гг.

§5: Н.В. Гоголь и Никитенко: новый тип реализма и нравственное перерождение в синтезе природы и духа. С. 20-21.

Захаров К.M. Мотивы игры в русских сатирических комедиях XIX века: Автореф. дис. ... д-ра филол. наук / Саратовский национальный исследовательский гос. ун-т им. Н.Г. Чернышевского. Саратов, 2017. 41 с.

Гл. 2: Мотивы Игры в драматургии Н.В. Гоголя.

§ 1: «Владимир Третьей степени». С. 15-17.

§ 2: «Игроки». С. 17-18.

§ 3: «Ревизор». С. 18-21.

$\S$ 4: «Женитьба». С. 21-23.

Автор-составитель:

Владимир Алексееевич Воропаев,

доктор филол. наук

профессор

филологический факультет

МГУ имени М.В. Ломоносова
Vladimir A. Voropaev,

Doctor of Philology

Professor

Philological Faculty

Lomonosov Moscow State University 